Article

\title{
Synthesis and Evaluation of Novel Ligustrazine Derivatives as Multi-Targeted Inhibitors for the Treatment of Alzheimer's Disease
}

\author{
Wenhao Wu ${ }^{\dagger} \mathbb{D}$, Xintong Liang ${ }^{\dagger}$, Guoquan Xie, Langdi Chen, Weixiong Liu, Guolin Luo, \\ Peiquan Zhang, Lihong Yu, Xuehua Zheng, Hong Ji, Chao Zhang * and Wei Yi *D
}

Key Laboratory of Molecular Target \& Clinical Pharmacology, School of Pharmaceutical Sciences, Guangzhou Medical University, Guangzhou 511436, Guangdong, China; wenhao_wu@gzhmu.edu.cn (W.W.); kilyte18@163.com (X.L.); guoquanxie@163.com (G.X.); chenlangdi427@gmail.com (L.C.); 13760781141@139.com (W.L.); 13570203692@163.com (G.L.); pqzhang@gzhmu.edu.cn (P.Z.); ylh84@126.com (L.Y.); zhengxh23@gzhmu.edu.cn (X.Z.); dljih@126.com (H.J.)

* Correspondence: chao-zh@163.com (C.Z.); yiwei@gzhmu.edu.cn (W.Y.); Tel.: +86-20-3710-3260 (C.Z.); +86-20-3710-4196 (W.Y.)

+ These authors contributed equally to this work.

Academic Editor: Pawel Kafarski

Received: 11 September 2018; Accepted: 1 October 2018; Published: 5 October 2018

\begin{abstract}
A series of novel ligustrazine derivatives 8a-r were designed, synthesized, and evaluated as multi-targeted inhibitors for anti-Alzheimer's disease (AD) drug discovery. The results showed that most of them exhibited a potent ability to inhibit both ChEs, with a high selectivity towards AChE. In particular, compounds $\mathbf{8 q}$ and $\mathbf{8 r}$ had the greatest inhibitory abilities for AChE, with $\mathrm{IC}_{50}$ values of 1.39 and $0.25 \mathrm{nM}$, respectively, and the highest selectivity towards $\mathrm{AChE}$ (for $\mathbf{8 q}, \mathrm{IC}_{50}$ $\mathrm{BuChE} / \mathrm{IC}_{50} \mathrm{AChE}=2.91 \times 10^{6}$; for $\mathbf{8 r}, \mathrm{IC}_{50} \mathrm{BuChE} / \mathrm{IC}_{50} \mathrm{AChE}=1.32 \times 10^{7}$ ). Of note, $\mathbf{8 q}$ and $\mathbf{8 r}$ also presented potent inhibitory activities against $\mathrm{A} \beta$ aggregation, with $\mathrm{IC}_{50}$ values of $17.36 \mu \mathrm{M}$ and $49.14 \mu \mathrm{M}$, respectively. Further cellular experiments demonstrated that the potent compounds $\mathbf{8 q}$ and 8r had no obvious cytotoxicity in either HepG2 cells or SH-SY5Y cells, even at a high concentration of $500 \mu \mathrm{M}$. Besides, a combined Lineweaver-Burk plot and molecular docking study revealed that these compounds might act as mixed-type inhibitors to exhibit such effects via selectively targeting both the catalytic active site (CAS) and the peripheral anionic site (PAS) of AChEs. Taken together, these results suggested that further development of these compounds should be of great interest.
\end{abstract}

Keywords: ligustrazine; acetylcholinesterase; self-induced $\mathrm{A} \beta$ aggregation; multi-targeted inhibitors; Alzheimer's disease

\section{Introduction}

Alzheimer's disease (AD) is a progressive neurodegenerative brain disorder that is manifested as dementia, cognitive impairment, memory loss, severe behavioral abnormalities, and ultimately death [1-4]. To date, AD is thought to be a complex, multifactorial syndrome, with many related molecular lesions contributing to its pathogenesis. Based on the existing hypothesis, AD is characterized as amyloid plaques, neurofibrillary tangles, inflammatory intermediates, and reactive oxygen species (ROS), and imposes neuronal death via a complex array of networked pathways [5].

According to the cholinergic hypothesis, the cognitive and memory deterioration of AD is due to a loss of cholinergic function in the central nervous system. Acetylcholinesterase (AChE) and butyrylcholinesterase (BuChE) are two major cholinesterases (ChE) involved in the hydrolysis and regulation of choline in vertebrates. Indeed, current treatment of AD mainly focuses on the inhibition of AChE activity in order to rectify the deficiency of cerebral acetylcholine [6,7]. However, the role 
of $\mathrm{BuChE}$ in the progression of $\mathrm{AD}$ has recently been proved. For instance, BuChE inhibitors could recover cholinergic activity through restoring the $\mathrm{AChE} / \mathrm{BuChE}$ activity ratios, as shown in a healthy brain [8], and BuChE may play a role in $\mathrm{AD}$ plaque due to its contribution to a subpopulation of $\mathrm{A} \beta$ plaques maturation by immunostaining analysis of AD brain tissues [9]. Nevertheless, many studies have showed that both ChEs could facilitate amyloid fibril formation to yield stable ChE-A $\beta$ complexes, which are more toxic than a single $A \beta$ peptide $[10,11]$. The complex of $A C h E$, through interaction with $A \beta$, promotes amyloid fibril formation through a spanning hydrophobic sequence exposed on the surface of AChE, which is close to the peripheral anionic binding site (PAS) and interacts with liposomes. Besides, an AChE-derived 35-residue peptide corresponding to the above hydrophobic sequence is incorporated into the growing $\mathrm{A} \beta$-fibrils. Therefore, drugs capable of inhibiting ChE might have beneficial therapy effects on the cognitive, functional, and behavioural symptoms of AD.

As a result, the development of the inhibitor targeting ChE, especially for AChE, has been an intensive research focus and a large number of $\mathrm{AChE}$ inhibitors have been reported thus far. Among them, those named "dual-site" AChE inhibitors occupy a particularly prominent position for the treatment of AD since they can interact with both the CAS and the PAS of AChE, leading to the potent activation of the cholinergic system, as well as the efficient inhibition of AChE-promoted A $\beta$ production and aggregation [12].

On the other hand, the multi-target approach has been proposed as particularly suitable for combating the heterogeneity and the multifactorial nature of AD [13]. Compared to single-targeted drugs, several pieces of literature have disclosed that, the candidate compound, possessing two or more distinct pharmacological properties closely related to the neurodegenerative process, is more effective in AD therapy [14-19]. Building on this strong foundation, ever-increasing efforts toward multi-target drug discovery are being made in the field for the treatment of AD [20].

Ligustrazine (tetramethylpyrazine (TMP), 1), one of the major efficacious components of the Chinese traditional medicine herb chuanxiong (Ligusticum wallichii), is widely used in China as a novel calcium channel antagonist for the treatment of coronary atherosclerotic cardiovascular disease and ischemic cerebrocardiac vascular disease [21]. TMP is also used with a combination of Rhizoma Curcumae Longae and Calculus bovis to treat cancer [22]. A preliminary pharmacokinetic investigation revealed that TMP could be rapidly absorbed into the blood and then crosses the blood-brain and blood-labyrinth barriers [23]. Recently, it was also reported that TMP could inhibit AChE, self-induced $A \beta$ aggregation, by acting as the potential antioxidant [24-26].

Motivated by the aforementioned information and in continuation of our interest in developing multi-target inhibitors as potent candidates for the treatment of AD [27], we herein disclose the design, synthesis, and biological evaluation of a series of novel ligustrazine-based derivatives as multi-targeted inhibitors against $\mathrm{AChE}, \mathrm{BChE}$, and $\mathrm{A} \beta$ aggregation for potent treatment of $\mathrm{AD}$. Furthermore, the structure-activity relationships (SARs) are discussed and the inhibition mechanism, the inhibitory kinetics, and the cytotoxicity of selected compounds are studied systematically. Taken together, our present results demonstrate that such compounds can serve as a promising candidate for the treatment of $\mathrm{AD}$ and establish a rational foundation for future design of new pharmacological agents as multi-target inhibitors of $\mathrm{AChE}, \mathrm{BChE}$, and $\mathrm{A} \beta$ aggregation.

\section{Results and Discussion}

\subsection{Chemistry}

The ligustrazine hybrids were conveniently synthesized according to the synthetic routes shown in Scheme 1. First, compound 5 was prepared based on a previous reported method [24]. Then, it was treated with 3-bromopropan-1-ol in the presence of EDC.HCl and DMAP to yield 3-bromopropyl 3,5,6-trimethylpyrazine-2-carboxylate 6 in a yield of 73\%. Finally, intermediate 6 was reacted with the corresponding carboxylic acid derivatives $7 \mathrm{a}-\mathrm{r}$ in the presence of DMF and anhydrous $\mathrm{K}_{2} \mathrm{CO}_{3}$ to afford the desired products $8 \mathbf{a}-\mathbf{r}$. The structures of synthesized compounds were confirmed by ${ }^{1} \mathrm{H}$ 
and ${ }^{13} \mathrm{C}$-NMR and HRMS. It should be noted that 3-(3,5,6-trimethylpyrazin-2-yl)acrylic acid (7q) was smoothly synthesized according to the literature, with a total yield of $60 \%$ [28].

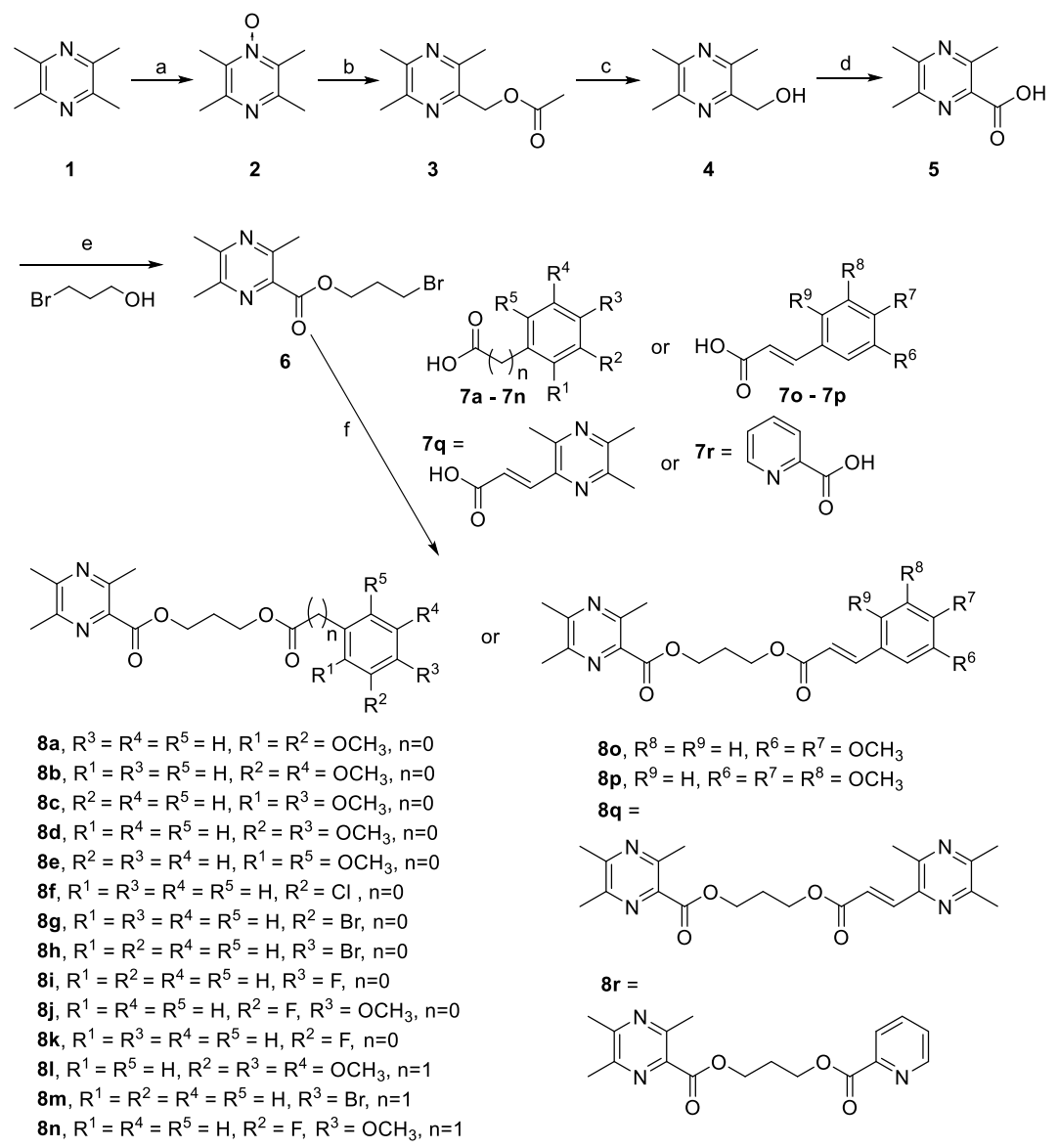

Scheme 1. Synthesis of novel ligustrazine hybrids. Reagents and conditions: (a) $30 \% \mathrm{H}_{2} \mathrm{O}_{2}, \mathrm{HOAc}$, $90{ }^{\circ} \mathrm{C}, 4 \mathrm{~h}$; (b) $\mathrm{Ac}_{2} \mathrm{O}$, reflux, $105^{\circ} \mathrm{C}, 2.5 \mathrm{~h}$; (c) $\mathrm{NaOH}$, THF: $\mathrm{MeOH}: \mathrm{H}_{2} \mathrm{O}$, r.t., 1 h; (d) $\mathrm{KMnO}_{4}, \mathrm{H}_{2} \mathrm{O}$, $50{ }^{\circ} \mathrm{C}, 12 \mathrm{~h}$; (e) EDC. $\mathrm{HCl}$, DMAP, $\mathrm{CH}_{2} \mathrm{Cl}_{2}$, r.t., $24 \mathrm{~h}$; (f) anhydrous $\mathrm{K}_{2} \mathrm{CO}_{3}, \mathrm{DMF}, 30^{\circ} \mathrm{C}, 12 \mathrm{~h}$.

\subsection{In Vitro Inhibition Studies on $A C h E, B u C h E$ and $A \beta$ (1-42) Self-Induced Aggregation.}

To determine the potential of the target compounds 8a-r for the treatment of AD, their AChE (from electric eel) and $\mathrm{BuChE}$ (from equine serum) inhibitory activities were evaluated by using the method of Ellman [29], in which tacrine and galanthamine were employed as the reference compounds. The $\mathrm{IC}_{50}$ values of all compounds for $\mathrm{ChEs}(\mathrm{AChE}$ and $\mathrm{BuChE}$ ) and the affinity ratios were summarized as shown in Table 1. The results demonstrated that most of the tested compounds had a potent capability to inhibit $\mathrm{AChE}$, even with an $\mathrm{IC}_{50}$ value at the nanomolar level. In sharp contrast, these compounds showed relatively weak inhibitory activities towards $\mathrm{BuChE}$ (with an $\mathrm{IC}_{50}$ value in the millimol grade). Obviously, these compounds displayed a good selectivity for $\mathrm{AChE}$ over $\mathrm{BuChE}$, and the ratios of $\mathrm{IC}_{50}$ $\mathrm{BuChE} / \mathrm{IC}_{50} \mathrm{AChE}$ affinity values ranged from $1.14 \times 10^{2}$ to $1.32 \times 10^{7}$.

As shown in Table 1, the reference compound-tacrine had a potent inhibitory activity, with an $\mathrm{IC}_{50}$ value of $73.36 \mathrm{nM}$, which was in good agreement with previous reports $[27,30]$. Interestingly, among these, compound $8 \mathbf{r}$, bearing a picolinic acid group, showed the most potent inhibition for AChE, with an $\mathrm{IC}_{50}$ value of $0.25 \mathrm{nM}$, and the potency was 293-times stronger than tacrine. However, its $\mathrm{IC}_{50}$ value against $\mathrm{BuChE}$ was $3.30 \mathrm{mM}$, which was much weaker than AChE. Moreover, the greatest selectivity index was also obtained for this compound, with an $\mathrm{IC}_{50} \mathrm{BuChE} / \mathrm{IC}_{50} \mathrm{AChE}$ value of $1.32 \times 10^{7}$. It indicated that compound $8 \mathbf{r}$ had an exclusive selectivity for AChE over BuChE. Furthermore, an SAR analysis suggested that the electron density of the benzene ring moiety in 
the product played a significant role in determining the inhibitory activity of AChE, and in general, the compounds bearing the electron-donating substituent exhibited more potent AChE inhibitory activity than those bearing the electron-withdrawing group. For instance, compounds $\mathbf{8 a}-\mathbf{8 e}$, in which the two methoxyl substituents were installed in different positions of the benzene ring, showed strong AChE inhibitory activities, with ranges of $\mathrm{IC}_{50}$ values from 4.12 to 387.9 nM. However, the homogeneous class of compounds $\mathbf{8 g}-\mathbf{h}$ and $\mathbf{8 m}$, bearing a bromo substituent in the benzene ring, exhibited relatively low AChE inhibitory activities compared with $\mathbf{8 a - e . ~}$

Table 1. Inhibition of ChEs activity, affinity ratios, and inhibition of $A \beta$ (1-42) self-induced aggregation ${ }^{a, b}$.

\begin{tabular}{|c|c|c|c|c|}
\hline Compounds & $\mathrm{IC}_{50}{ }^{\mathrm{c}}$ for $\mathrm{AChE}(\mathrm{nM})$ & $\mathrm{IC}_{50}$ for BuChE (mM) & Selectivity Index ${ }^{f}$ & $\begin{array}{c}\mathrm{IC}_{50} \text { for } \mathrm{A} \beta(\mathbf{1 - 4 2 )} \\
\text { Aggregation }(\mu \mathrm{M}) \mathrm{g}\end{array}$ \\
\hline $8 a$ & $167.9 \pm 0.39$ & $3.63 \pm 0.07$ & $2.16 \times 10^{4}$ & NA \\
\hline $8 b$ & $4.43 \pm 0.35$ & $5.64 \pm 0.38$ & $1.27 \times 10^{6}$ & $3.66 \pm 0.104$ \\
\hline $8 c$ & $387.9 \pm 0.45$ & $2.70 \pm 0.03$ & $5.16 \times 10^{3}$ & $22.54 \pm 0.014$ \\
\hline $8 d$ & $4.12 \pm 0.24$ & $4.29 \pm 0.12$ & $1.02 \times 10^{6}$ & $51.81 \pm 0.047$ \\
\hline $8 e$ & $143.8 \pm 0.25$ & $0.34 \pm 0.03$ & $2.36 \times 10^{3}$ & $55.86 \pm 0.035$ \\
\hline $8 f$ & $6.61 \pm 0.13$ & $3.27 \pm 0.06$ & $4.95 \times 10^{5}$ & $45.88 \pm 0.024$ \\
\hline $8 g$ & $\mathrm{NA}^{\mathrm{d}}$ & $21.13 \pm 0.46$ & 6.23 & NA \\
\hline $8 \mathrm{~h}$ & NA & $2.49 \pm 0.29$ & 2.62 & NA \\
\hline $8 \mathbf{i}$ & NA & $112.74 \pm 0.47$ & $1.14 \times 10^{2}$ & $211.18 \pm 0.039$ \\
\hline $8 \mathbf{j}$ & NA & $0.857 \pm 0.002$ & 2.97 & $7.12 \pm 0.012$ \\
\hline $8 \mathrm{k}$ & NA & $5.49 \pm 0.15$ & 9.49 & $5.10 \pm 0.040$ \\
\hline 81 & $303.4 \pm 0.26$ & $3.96 \pm 0.26$ & $1.31 \times 10^{4}$ & $77.45 \pm 0.029$ \\
\hline $8 \mathrm{~m}$ & NA & $373.52 \pm 0.78$ & 52.17 & $200.84 \pm 0.016$ \\
\hline $8 n$ & NA & $3.06 \pm 0.34$ & 20.67 & NA \\
\hline 80 & $3.24 \pm 0.10$ & $3.97 \pm 0.10$ & $1.23 \times 10^{6}$ & $45.29 \pm 0.033$ \\
\hline $8 p$ & $93.51 \pm 0.20$ & $4.02 \pm 0.03$ & $4.30 \times 10^{4}$ & $71.28 \pm 0.044$ \\
\hline $8 q$ & $1.39 \pm 0.33$ & $4.04 \pm 0.91$ & $2.91 \times 10^{6}$ & $17.36 \pm 0.027$ \\
\hline $8 r$ & $0.25 \pm 0.39$ & $3.30 \pm 0.06$ & $1.32 \times 10^{7}$ & $49.14 \pm 0.025$ \\
\hline Tacrine & $73.36 \pm 0.22$ & $14.45 \pm 0.06^{\mathrm{e}}$ & 0.20 & $12.21 \pm 0.02$ \\
\hline Galanthamine & $23.74 \pm 0.06$ & $0.180 \pm 0.004$ & $7.58 \times 10^{3}$ & NA \\
\hline
\end{tabular}

${ }^{a}$ Data was expressed as mean \pm SEM of at least three independent experiments. ${ }^{b}$ All tested compounds were soluble at a final concentration in each assay. ${ }^{\mathrm{c}} \mathrm{IC}_{50}$, inhibitor concentration for $50 \%$ inactivation of AChE. ${ }^{\mathrm{d}}$ No potent inhibitory activity. ${ }^{\mathrm{e}}$ Unit of $\mathrm{nM}$ (nanomolar). ${ }^{\mathrm{f}}$ Selectivity index $=\mathrm{IC}_{50}(\mathrm{BChE}) / \mathrm{IC}_{50}$ (AChE). ${ }^{\mathrm{g}}$ The thioflavin-T fluorescence method was used and the measurements were carried out in the presence of $0,5,10,20,50,100,150$, 200, 250, and $300 \mu \mathrm{M}$ tested compounds, respectively.

Moreover, compounds 81-n exhibited AChE inhibitory effects, with $\mathrm{IC}_{50}$ values that ranged from $303.4 \mu \mathrm{M}$ to $7.16 \mathrm{mM}$, which was less active than $8 \mathbf{a}-\mathbf{k}$ (from $4.12 \mathrm{nM}$ to $993.39 \mu \mathrm{M}$ ), suggesting that the introduction of the methylene part between the ester group and the benzene ring was harmful to AChE inhibitory activity. Interestingly, the introduction of the conjugated vinyl group into $8 \mathrm{~d}$ that gave the compound 8o, demonstrated potent $\mathrm{AChE}$ inhibitory effects, with an $\mathrm{IC}_{50}$ value of $3.24 \mathrm{nM}$. A similar conclusion was observed in comparison with 81 and $\mathbf{8 p}$. The results revealed that the introduction of a proper and relatively rigid group between the ester group and the benzene ring was beneficial to AChE inhibitory activity. Of note, replacement of the benzene ring moiety with the $N$-heterocyclic ring, such as pyrazine or pyridine, led to a dramatic increase in inhibitory activity, since the obtained compounds $\mathbf{8 q}$ and $\mathbf{8 r}$ were found to be the most potent inhibitors of $\mathrm{AChE}$, with excellent selectivity towards AChE (for 8q, $\mathrm{IC}_{50}=1.39 \mathrm{nM}, \mathrm{IC}_{50} \mathrm{BuChE} / \mathrm{IC}_{50} \mathrm{AChE}=1.32 \times 10^{7}$; for $\mathbf{8 r}, \mathrm{IC}_{50}=0.25 \mathrm{nM}$, $\left.\mathrm{IC}_{50} \mathrm{BuChE} / \mathrm{IC}_{50} \mathrm{AChE}=2.91 \times 10^{6}\right)$, indicating that the introduction of the nitrogen atom contributed to AChE inhibitory activities, probably due to the additional affinity with the active pocket of AChE.

Inspired by the above results, these synthesized compounds were further tested for their abilities to inhibit self-mediated aggregation of $A \beta(1-42)$ by using a thioflavin-T fluorescence method [29] and employing the well-known tacrine as a standard reference. As summarized in Table 1 , the results showed that most of the ligustrazine derivatives apparently prevented self-mediated $\mathrm{A} \beta$ aggregation. In particular, compounds $\mathbf{8 b}\left(\mathrm{IC}_{50}=3.66 \mu \mathrm{M}\right), \mathbf{8 j}\left(\mathrm{IC}_{50}=7.12 \mu \mathrm{M}\right)$, and $\mathbf{8 k}\left(\mathrm{IC}_{50}=5.10 \mu \mathrm{M}\right)$ showed higher potency than that of the reference compound tacrine $(12.21 \mu \mathrm{M})$. Gratefully, the two best 
potent AChE inhibitors $\mathbf{8 q}$ and $\mathbf{8 r}$ also possessed acceptable inhibitory activities against self-induced $\mathrm{A} \beta$ (1-42) aggregation, with $\mathrm{IC}_{50}$ values of $17.36 \mu \mathrm{M}$ and $49.14 \mu \mathrm{M}$, respectively. Taken together, the data from the ChEs and $A \beta$ aggregation test revealed that these developed compounds might act as novel multi-targeted "hits" for potent anti-AD drug discovery. Thus, further development of such compounds should be of great interest.

\subsection{Inhibition of $A \beta$ (1-42) Fibril Formation Monitored by Transmission Electron Microscopy (TEM)}

To further confirm the ability of these compounds in inhibiting A $\beta$ (1-42) aggregation, the inhibitory activity of the selected compound $\mathbf{8 q}$ was monitored by using TEM [31]. As shown in Figure 1, after $24 \mathrm{~h}$ of incubation at $37^{\circ} \mathrm{C}, \mathrm{A} \beta(1-42)$ alone aggregated into well-defined $\mathrm{A} \beta$ fibrils and amorphous deposits were observed (Figure $1 \mathrm{a}, \mathrm{b}$ ). In sharp contrast, no obvious $\mathrm{A} \beta$ fibril was detected in the presence of either tacrine or $\mathbf{8 q}$ (Figure $1 c, d$ ) under identical conditions. Moreover, compound $\mathbf{8 q}$ could obviously alleviate the formation of $A \beta$ amorphous deposits compared with tacrine. These results were in agreement with the data from the thioflavin-T fluorescence experiment, also suggesting that $\mathbf{8 q}$ can serve as a promising candidate for the treatment of AD.

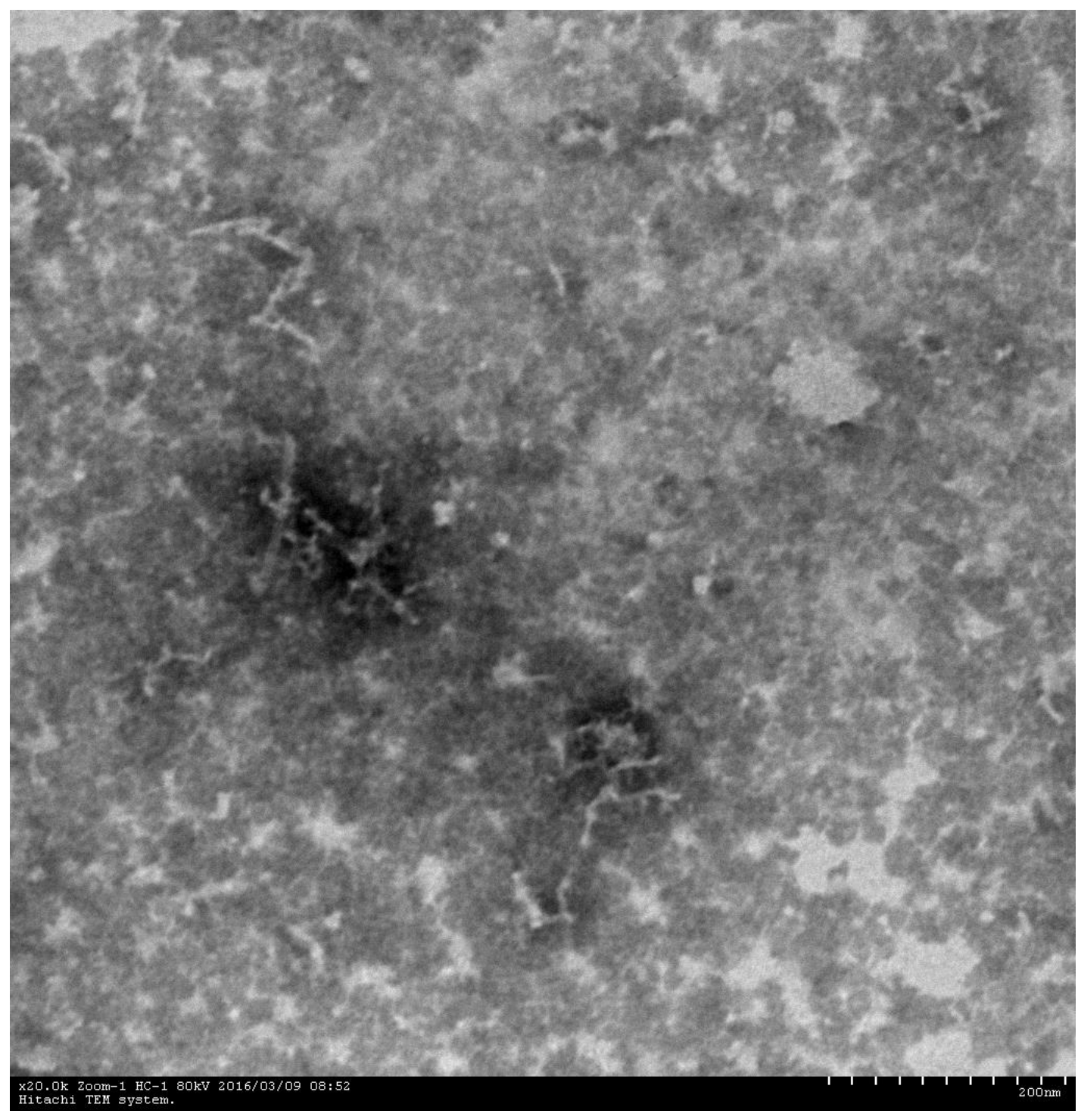

(a) $\mathrm{A} \beta$ (1-42) alone (0 h)

Figure 1. Cont. 


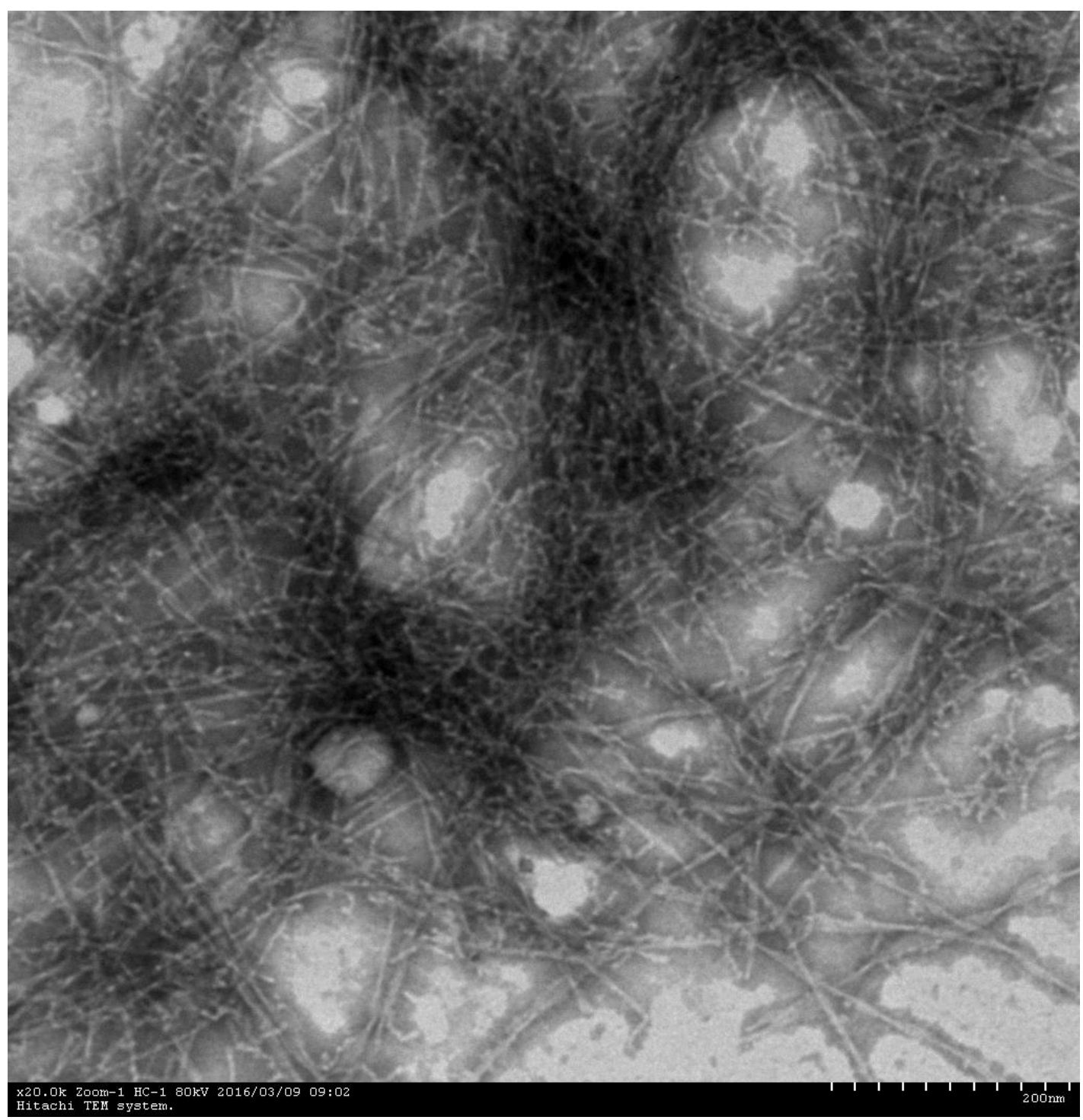

(b) $\mathrm{A} \beta$ (1-42) alone (24 h)

Figure 1. Cont. 


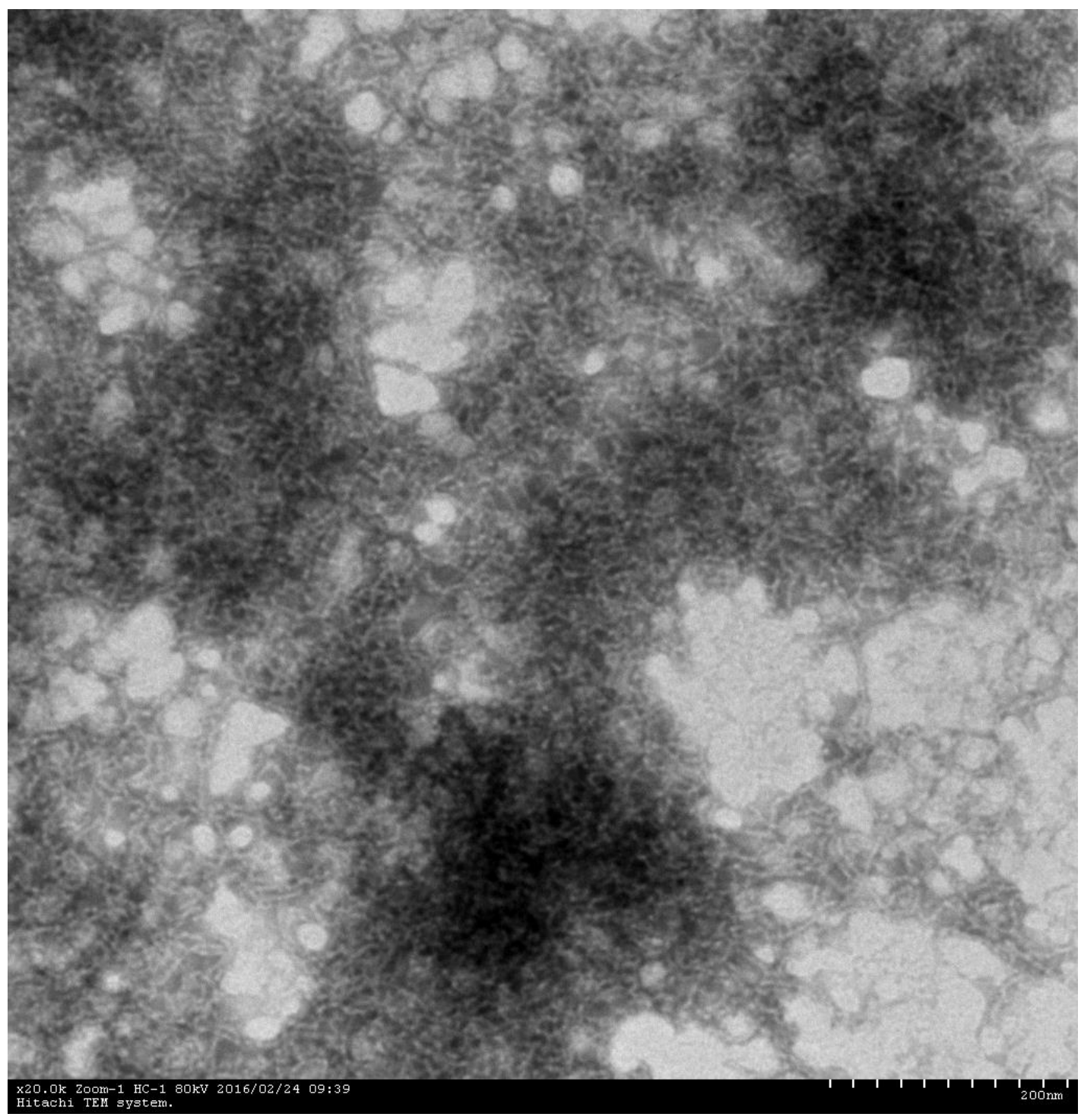

(c) $A \beta(1-42)+$ tacrine $(24 \mathrm{~h})$

Figure 1. Cont. 


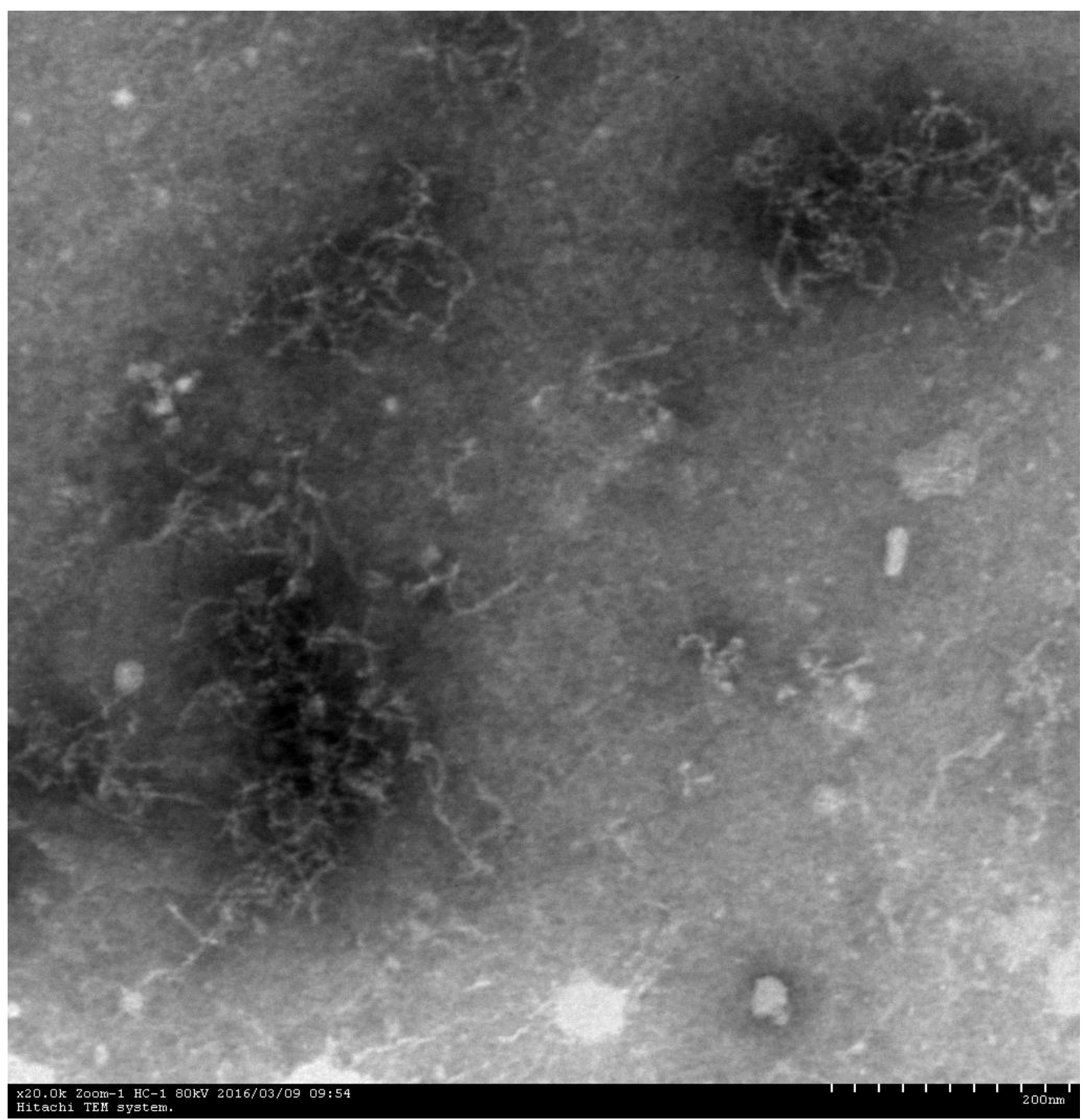

(d) $A \beta(1-42)+8 q(24 h)$

Figure 1. TEM image analysis of $A \beta$ (1-42) aggregation. (a) $A \beta(1-42)$ alone $(20 \mu \mathrm{M})$ was incubated at $37^{\circ} \mathrm{C}$ for $0 \mathrm{~h}$; (b) A $\beta(1-42)$ alone $(20 \mu \mathrm{M})$ was incubated at $37^{\circ} \mathrm{C}$ for $24 \mathrm{~h}$; (c)A $\beta(1-42)(20 \mu \mathrm{M})$ and tacrine $(50 \mu \mathrm{M})$ were incubated at $37^{\circ} \mathrm{C}$ for $24 \mathrm{~h}$; (d) A $\beta(1-42)(20 \mu \mathrm{M})$ and $8 \mathbf{8 q}(50 \mu \mathrm{M})$ were incubated at $37^{\circ} \mathrm{C}$ for $24 \mathrm{~h}$.

\subsection{Kinetic Characterization of AChE Inhibition}

Encouraged by the above results, we further selected the most potent AChE inhibitor $\mathbf{8 q}$ for kinetic analysis to uncover the inhibition mechanism by using the graphical analysis of the reciprocal Lineweaver-Burk plot. As demonstrated in Figure 2, the results showed that the plots of 1/V versus $1 /[\mathrm{S}]$ gave a family of straight lines, with different slopes that intersected one another in the second quadrant. With the increase of the concentration of $\mathbf{8 q}$, the values of Vmax descended, but the values of $\mathrm{Km}$ kept increasing, indicating that it was a mixed-type inhibitor of AChE. 


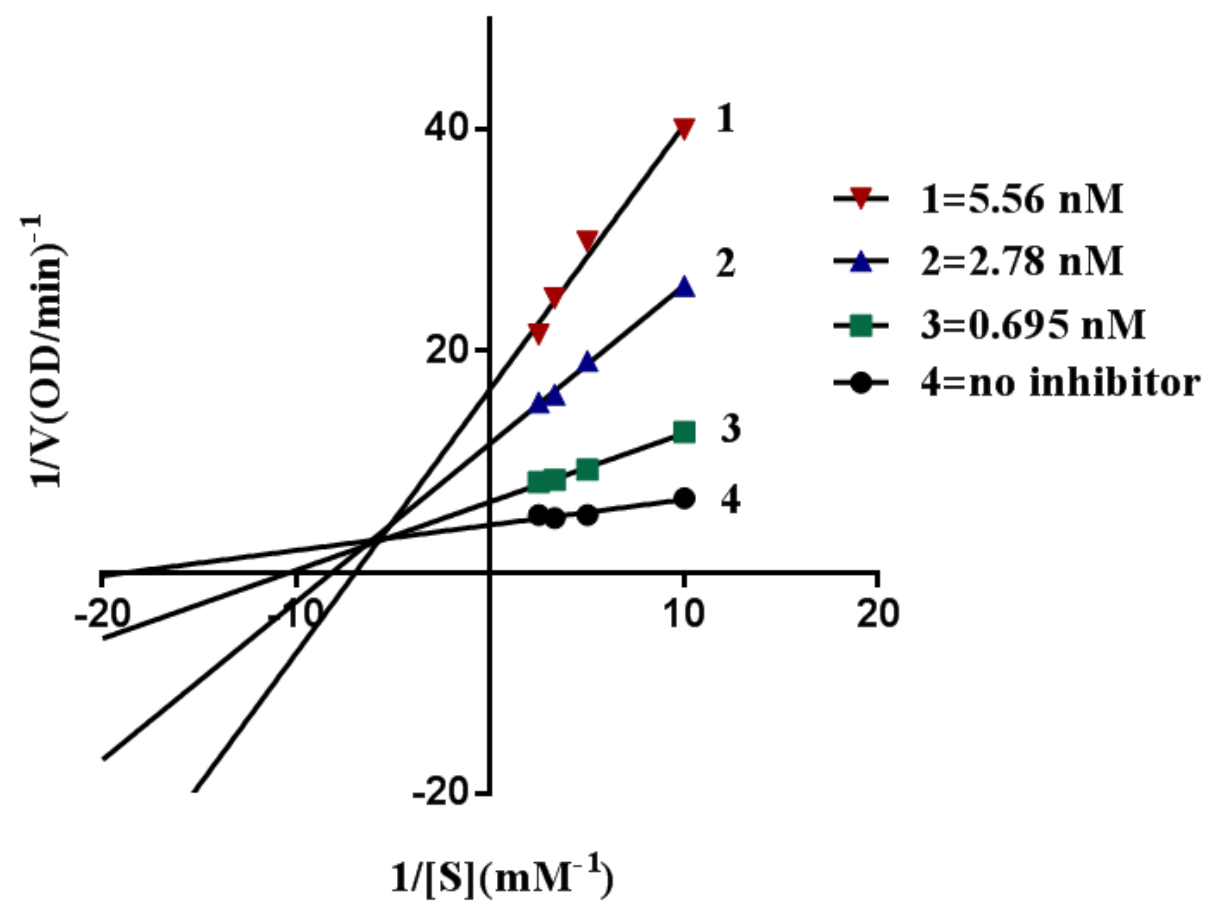

Figure 2. Determination of the inhibitory type of selected compound $\mathbf{8 q}$ on AChE. Merged Lineweaver-Burk reciprocal plots of AChE initial velocity with increasing substrate concentrations $(0.1-0.4 \mathrm{mM})$ in the absence or presence of $\mathbf{8 q}$. Lines were derived from a weighted least-squares analysis of data points.

\subsection{Molecular Modeling Study of AChE}

To gain further insight into the molecular basis, the most active compounds $\mathbf{8 q}$ and $\mathbf{8 r}$ were selected to dock into the active site of TcAChE. It is well-known that, in previous crystallographic studies, significant conformation changes were observed in the active site of TcAChE [31-35]. For example, bis-tacrine derivatives with a 7-carbon spacer (PDB code $2 \mathrm{ckm}$ ) induced the rotation of side chains of Tyr70 and Trp279 to promote the sandwich interaction with the active PAS site in the pocket of AChE, while their analogues with a 5-carbon spacer (PDB code $2 \mathrm{cmf}$ ) caused the structural alteration of Trp279-Ser291's loop in the CAS site [32]. Based on this information, we herein used $2 \mathrm{ckm}$ and $2 \mathrm{cmf}$ as molecular modeling for $\mathbf{8 q}$ containing a 7 -carbon spacer and $8 \mathbf{r}$ with a 5-carbon spacer, respectively. The results showed that no large-scale structural displacement occurred in $\mathbf{8 q}$ or $8 \mathrm{r}$ binding to $\mathrm{AChE}$, mainly due to their small molecular size compared with tacrine derivatives. Alternatively, the crystal structure of the HupA-TcAChE complex (PDB code 1vot), where most residues were retained in the native conformations, was chosen as the molecular docking model [33]. Gratefully, re-docking of the original ligand into the active site gave an acceptable RMSD difference of 0.5384, which verified the reliability of our strategy. Figure 3 shows that both $\mathbf{8 q}$ and $\mathbf{8 r}$ spanned the active gorge with an extended conformation. The proximal pyrazine ring was bound in the CAS at the bottom, stacking against the side chain of Trp84, while the distal pyrazine/pyridine ring was present in the PAS near the mouth, forming a $\pi-\pi$ interaction with Trp279. Moreover, some hydrophobic or van der Waals interactions might occur between $\mathbf{8 q}$ or $\mathbf{8 r}$ and the surrounding residues, such as Tyr70, Asp72, Asn85, Gly119, Tyr121, Ser122, Gly123, Tyr130, Leu282, Ser286, Ile287, Phe288, Phe290, Phe330, Phe331, Tyr334, Gly335, Trp432, His440, and Tyr442. Such interactions all contributed to their potent affinities with AChE. It should be noted that, owing to the fact that BuChE did not have the PAS [36], these compounds could not form effective binding interactions with the active pocket of BuChE, thereby giving a specific selectivity towards AChE. Finally, the result also revealed that compound $\mathbf{8 q}$ could bind to both the CAS and the PAS of AChE. 


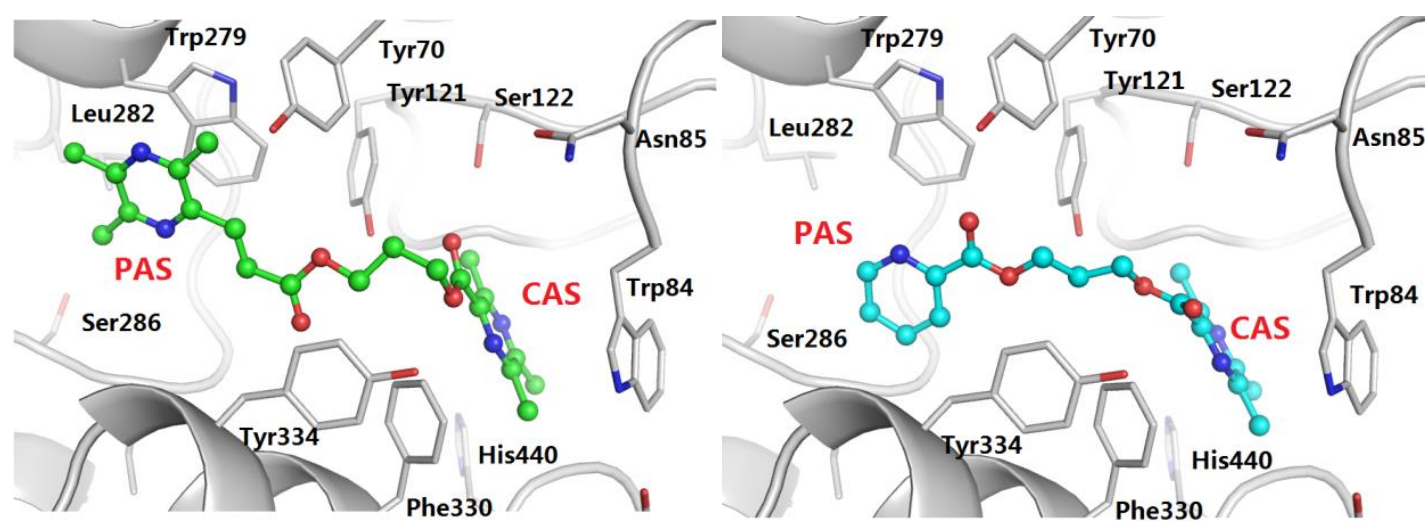

Figure 3. Binding modes of $\mathbf{8 q}$ (green carbon) and $\mathbf{8 r}$ (cyan carbon) obtained from molecular docking. Surrounding residues are depicted in grey (carbon), red (oxygen), and blue (nitrogen).

\subsection{Cytotoxicity Assay for $\mathbf{8 q}$ and $\mathbf{8 r}$}

One of the best documented side-effects of the drug discovery and development of $\mathrm{AD}$ is cytotoxicity [37-39]. To probe whether such a type of target compounds involves cytotoxic effects, we respectively treated HepG2 cells and SH-SY5Y cells with several concentrations of the corresponding compound. Cell viability was determined by a CCK-8 assay. As reported, the referenced compound tacrine showed dose-dependent cytotoxicity (Tables 2 and 3). Excitedly, our potent "hits" $8 q$ and $8 \mathbf{r}$ displayed no obvious cytotoxicity in the two cell lines, even at a high concentration of $500 \mu \mathrm{M}$, suggesting that potent compounds $\mathbf{8 q}$ and $\mathbf{8 r}$ have a potent safe window for the next stage of the development of anti-AD drug discovery.

Table 2. In vitro cytotoxicity of tacrine and ligustrazine hybrids $\mathbf{8 q}$ and $\mathbf{8 r}$ in HepG2 cells ${ }^{\text {a,b }}$.

\begin{tabular}{ccccccccc}
\hline Compounds & Control & $\mathbf{2 5} \boldsymbol{\mu \mathbf { M }}$ & $\mathbf{5 0} \boldsymbol{\mu \mathbf { M }}$ & $\mathbf{1 2 5} \boldsymbol{\mu \mathbf { M }}$ & $\mathbf{2 0 0} \boldsymbol{\mu \mathbf { M }}$ & $\mathbf{3 0 0} \boldsymbol{\mu \mathbf { M }}$ & $\mathbf{4 0 0} \boldsymbol{\mu \mathbf { M }}$ & $\mathbf{5 0 0} \boldsymbol{\mu \mathbf { M }}$ \\
\hline $\mathbf{8 q}$ & $100 \pm 0.82$ & $96.81 \pm 3.05^{\mathrm{ns}}$ & $91.09 \pm 0.99^{\mathrm{ns}}$ & $81.19 \pm 1.48^{* *}$ & $64.81 \pm 0.54^{* *}$ & $66.75 \pm 1.11^{* *}$ & $68.89 \pm 0.51^{* *}$ & $70.10 \pm 1.98^{* *}$ \\
$\mathbf{8 r}$ & $100 \pm 0.86$ & $102.83^{*} \pm 0.57^{\mathrm{ns}}$ & $88.05 \pm 1.12^{\mathrm{ns}}$ & $81.72 \pm 0.87^{* *}$ & $71.10 \pm 1.06^{* *}$ & $71.10 \pm 0.80^{* *}$ & $68.85 \pm 1.11^{* *}$ & $68.31 \pm 0.53^{* *}$ \\
Tacrine & $100 \pm 2.87$ & $99.78 \pm 1.07^{\mathrm{ns}}$ & $95.02 \pm 2.30^{\mathrm{ns}}$ & $83.72 \pm 0.73^{* *}$ & $81.80 \pm 1.86^{* *}$ & $74.32 \pm 3.93^{* *}$ & $23.61 \pm 0.05^{* *}$ & $19.92 \pm 0.05^{* *}$ \\
\hline
\end{tabular}

${ }^{a}$ Cell viability was determined by a Cell Counting Kit-8 (CCK-8) assay and all compounds were assayed at increasing concentrations $\left(1-500 \mu \mathrm{M}\right.$, as indicated); ${ }^{b}$ Data are normalized as a percentage of control and are expressed as the means \pm SEM of triplicates from at least three different cultures. ${ }^{* *} p \leq 0.01{ }^{\text {ns }}$ Not significant with respect to the control group.

Table 3. In vitro cytotoxicity of tacrine and compounds $8 \mathbf{q}$ and $8 \mathrm{r}$ in SH-SY5Y cells ${ }^{\mathrm{a}, \mathrm{b}}$.

\begin{tabular}{ccccccccc}
\hline Compounds & Control & $\mathbf{2 5} \boldsymbol{\mu M}$ & $\mathbf{5 0} \boldsymbol{\mu M}$ & $\mathbf{1 2 5} \boldsymbol{M} \mathbf{M}$ & $\mathbf{2 0 0 \mu \mathbf { M }}$ & $\mathbf{3 0 0} \boldsymbol{\mu M}$ & $\mathbf{4 0 0} \boldsymbol{\mu M}$ & $\mathbf{5 0 0} \boldsymbol{\mu M}$ \\
\hline $\mathbf{8 q}$ & $100 \pm 0.28$ & $104.30 \pm 0.29^{\mathrm{ns}}$ & $96.08 \pm 0.78^{\mathrm{ns}}$ & $80.25 \pm 1.53^{* *}$ & $72.17 \pm 0.54^{* *}$ & $58.92 \pm 0.70^{* *}$ & $55.14 \pm 0.50^{* *}$ & $55.28 \pm 0.55^{* *}$ \\
$\mathbf{8 r}$ & $100 \pm 1.75$ & $94.51 \pm 0.45^{\mathrm{ns}}$ & $91.46 \pm 0.29^{\mathrm{ns}}$ & $83.23 \pm 0.78^{*}$ & $83.26 \pm 2.74^{*}$ & $68.43 \pm 0.48^{* *}$ & $62.68 \pm 0.56^{* *}$ & $66.38 \pm 1.57^{* *}$ \\
Tacrine & $100 \pm 1.86$ & $87.89 \pm 0.85^{\mathrm{ns}}$ & $88.17 \pm 1.55^{\mathrm{ns}}$ & $75.42 \pm 0.78^{* *}$ & $48.75 \pm 0.43^{* *}$ & $43.39 \pm 2.69^{* *}$ & $34.69 \pm 2.86^{* *}$ & $27.93 \pm 1.44^{* *}$ \\
\hline
\end{tabular}

a Cell viability was determined by a Cell Counting Kit-8 (CCK-8) assay and all compounds were assayed at increasing concentrations $\left(1-500 \mu \mathrm{M}\right.$, as indicated); ${ }^{\mathrm{b}}$ Data are normalized as a percentage of the control and are expressed as the means \pm SEM of triplicates from at least three different cultures. ${ }^{* *} p \leq 0.01$. ${ }^{*} p \leq 0.05$ ns Not significant with respect to the control group.

\section{Materials and Methods}

\subsection{Chemistry}

All commercially available compounds and dried solvents were used without further purification. The NMR $\left({ }^{1} \mathrm{H}\right.$ and $\left.{ }^{13} \mathrm{C}\right)$ spectra were recorded on a Bruker Avnace III 400 spectrometer (Bruker Avnace, Billerica, MA, USA) or Varian Mercury-Plus 300 spectrometer (Palo Alto, CA, USA). Chemical shifts ( $\delta$ ) were referenced to TMS as an internal standard. Coupling constants are given in Hz. MS spectra were obtained on an Agilent 6330 Ion Trap Mass Spectrometer (Palo Alto, CA, USA). HRMS spectra were recorded on a Shimazu LCMS-IT-TOF mass spectrometer (Kyoto, Japan). Microscopy images were captured on a HITACHI H-7650 transmission electron microscope (Tokyo, Japan). TLC was monitored 
by precoated silica gel GF254 plates purchased from Merck\& Co., (Darmstadt, Germany) and the spots were detected through a UV lamp (Yuhua Co. Ltd., Guangzhou, China) at $254 \mathrm{~nm}$. Flash column chromatography was performed with silica gel (200-300 mesh) purchased from Qingdao Haiyang Chemical Co. Ltd., Qingdao, China.

\subsection{Synthesis of Intermediate 6}

3-Bromopropan-1-ol was added dropwise to an ice-cold solution of 5 (20.0 mmol), DMAP (10 mg), and $\mathrm{EDC} \cdot \mathrm{HCl}(52 \mathrm{mmol})$ in $\mathrm{CH}_{2} \mathrm{Cl}_{2}(20 \mathrm{~mL})$. After the addition had been completed, the mixture was allowed to adjust to room temperature and was stirred for $24 \mathrm{~h}$. When the reaction had been monitored by TLC, the solvent was removed in vacuum. The obtained brown residue was dissolved by adding distilled water, extracted with EtOAc three times $(50 \mathrm{~mL} \times 3)$, and washed with water. The organic layer was washed with brine dried over anhydrous $\mathrm{Na}_{2} \mathrm{SO}_{4}$. It was concentrated under reduced pressure to give compound $6(2.08 \mathrm{~g})$ as tan jelly without further purification. The yield was $73 \%$.

\subsection{General Procedures for the Preparation of $\mathbf{8 a}-\mathbf{r}$}

To a solution of $7(1.22 \mathrm{mmol})$ in DMF $(2 \mathrm{~mL})$, anhydrous $\mathrm{K}_{2} \mathrm{CO}_{3}(1.62 \mathrm{mmol})$ was first added, $6(0.81 \mathrm{mmol})$ in DMF $(2 \mathrm{~mL})$ was then added dropwise, and the reaction mixture was stirred at $30{ }^{\circ} \mathrm{C}$ for $3 \mathrm{~h}$. When the reaction was completed, the mixture was diluted with water $(20 \mathrm{~mL})$ and extracted with EtOAc $(25 \mathrm{~mL} \times 3)$. The organic layer was washed with brine, dried over anhydrous $\mathrm{Na}_{2} \mathrm{SO}_{4}$, and concentrated under reduced pressure. The obtained residue was purified by silica gel chromatography to afford the desire product.

3-[(2,3-Dimethoxybenzoyl)oxy]propyl 3,5,6-trimethylpyrazine-2-carboxylate (8a). Compound 6 was treated with 2,3-dimethoxybenzoic acid (7a) according to general procedure to give the desired product $8 \mathbf{a}$ as a white solid. Yield 48\%, ${ }^{1} \mathrm{H}-\mathrm{NMR}\left(\mathrm{CDCl}_{3}, 300 \mathrm{MHz}\right) \delta(\mathrm{ppm}): 2.29(\mathrm{p}, J=6.3 \mathrm{~Hz}, 2 \mathrm{H}), 2.56(\mathrm{~s}, 6 \mathrm{H})$, $2.74(\mathrm{~s}, 3 \mathrm{H}), 3.90(\mathrm{~d}, J=8.5 \mathrm{~Hz}, 6 \mathrm{H}), 4.48(\mathrm{t}, J=6.2 \mathrm{~Hz}, 2 \mathrm{H}), 4.58(\mathrm{t}, J=6.5 \mathrm{~Hz}, 2 \mathrm{H}), 7.06(\mathrm{~d}, J=3.9 \mathrm{~Hz}$, 2H), 7.38-7.27 (m, 1H) ${ }^{13} \mathrm{C}-\mathrm{NMR}\left(\mathrm{CDCl}_{3}, 75 \mathrm{MHz}\right) \delta(\mathrm{ppm}): 21.55,22.17,22.57,28.07,56.05,61.58(\mathrm{~d}$, $J=14.0 \mathrm{~Hz}), 62.56,115.86,122.19,123.80,125.95,139.40,149.18(\mathrm{~d}, J=16.3 \mathrm{~Hz}), 151.13,153.52,154.50$, 165.91, 166.18. ESI-HRMS Calcd. for $\mathrm{C}_{20} \mathrm{H}_{24} \mathrm{~N}_{2} \mathrm{O}_{6}[\mathrm{M}+\mathrm{Na}]^{+}$: 411.1527; found: 411.1532.

3-[(3,5-Dimethoxybenzoyl)oxy]propyl 3,5,6-trimethylpyrazine-2-carboxylate (8b). Compound $\mathbf{6}$ was treated with 3,5-dimethoxybenzoic acid $(\mathbf{7 b})$ according to general procedure to give the desired product $\mathbf{8 b}$ as a white solid. Yield $46 \%,{ }^{1} \mathrm{H}-\mathrm{NMR}\left(\mathrm{CDCl}_{3}, 300 \mathrm{MHz}\right) \delta(\mathrm{ppm}): 2.30(\mathrm{p}, J=6.3 \mathrm{~Hz}, 2 \mathrm{H}), 2.54(\mathrm{~s}, 3 \mathrm{H}), 2.56$ $(\mathrm{s}, 3 \mathrm{H}), 2.73(\mathrm{~s}, 3 \mathrm{H}), 3.82(\mathrm{~s}, 6 \mathrm{H}), 4.49(\mathrm{t}, J=6.2 \mathrm{~Hz}, 1 \mathrm{H}), 4.58(\mathrm{t}, J=6.4 \mathrm{~Hz}, 1 \mathrm{H}), 6.63(\mathrm{t}, J=2.4 \mathrm{~Hz}, 1 \mathrm{H})$, $7.15(\mathrm{~d}, J=2.4 \mathrm{~Hz}, 2 \mathrm{H}) .{ }^{13} \mathrm{C}-\mathrm{NMR}\left(\mathrm{CDCl}_{3}, 75 \mathrm{MHz}\right) \delta(\mathrm{ppm}): 21.53,22.15,22.57,28.10,55.54,61.87,62.60$, $105.61,107.14(\mathrm{~d}, J=4.4 \mathrm{~Hz}), 131.87,139.29,149.26,151.19,154.52,160.58,165.86,166.19$. ESI-HRMS Calcd. for $\mathrm{C}_{20} \mathrm{H}_{24} \mathrm{~N}_{2} \mathrm{O}_{6}[\mathrm{M}+\mathrm{Na}]^{+}$: 411.1527; found: 411.1535.

3-[(2,4-Dimethoxybenzoyl)oxy]propyl 3,5,6-trimethylpyrazine-2-carboxylate (8c). Compound 6 was treated with 2,4-dimethoxybenzoic acid (7c) according to general procedure to give the desired product $8 \mathbf{c}$ as a white solid. Yield 48\%, ${ }^{1} \mathrm{H}-\mathrm{NMR}\left(\mathrm{CDCl}_{3}, 300 \mathrm{MHz}\right) \delta(\mathrm{ppm}): 2.26(\mathrm{~m}, 2 \mathrm{H}), 2.54(\mathrm{~s}, 6 \mathrm{H}), 2.71(\mathrm{~s}, 3 \mathrm{H}), 3.86$ $(\mathrm{s}, 3 \mathrm{H}), 3.89(\mathrm{~s}, 3 \mathrm{H}), 4.45(\mathrm{t}, J=6.2 \mathrm{~Hz}, 2 \mathrm{H}), 4.55(\mathrm{t}, J=6.5 \mathrm{~Hz}, 2 \mathrm{H}), 7.03(\mathrm{~s}, 1 \mathrm{H}), 7.04(\mathrm{~d}, J=1.7 \mathrm{~Hz}, 1 \mathrm{H})$, $7.28(\mathrm{dd}, J=5.5,3.9 \mathrm{~Hz}, 1 \mathrm{H}) .{ }^{13} \mathrm{C}-\mathrm{NMR}\left(\mathrm{CDCl}_{3}, 75 \mathrm{MHz}\right) \delta(\mathrm{ppm}): 21.53,22.14,22.54,28.05,56.02,61.55$, $62.53,115.87,122.20,123.78,125.92,139.37,149.15,151.09,153.50,154.47,165.88,166.15$. ESI-HRMS Calcd. for $\mathrm{C}_{20} \mathrm{H}_{24} \mathrm{~N}_{2} \mathrm{O}_{6}[\mathrm{M}+\mathrm{Na}]^{+}$: 411.1527; found: 411.1538 .

3-[(3,4-Dimethoxybenzoyl)oxy]propyl 3,5,6-trimethylpyrazine-2-carboxylate (8d). Compound 6 was treated with 3,4-dimethoxybenzoic acid (7d) according to general procedure to give the desired product $\mathbf{8 d}$ as a white solid. Yield $41 \%,{ }^{1} \mathrm{H}-\mathrm{NMR}\left(d_{6}\right.$-DMSO, $\left.400 \mathrm{MHz}\right) \delta(\mathrm{ppm}): 2.18(\mathrm{~m}, 2 \mathrm{H}), 2.43(\mathrm{~s}, 3 \mathrm{H}), 2.48$ $(\mathrm{s}, 3 \mathrm{H}), 2.57(\mathrm{~s}, 3 \mathrm{H}), 3.77(\mathrm{~s}, 3 \mathrm{H}), 3.83(\mathrm{~s}, 3 \mathrm{H}), 4.38(\mathrm{t}, J=6.1 \mathrm{~Hz}, 2 \mathrm{H}), 4.47(\mathrm{t}, J=6.2 \mathrm{~Hz}, 2 \mathrm{H}), 7.00(\mathrm{~d}$, $J=8.5 \mathrm{~Hz}, 1 \mathrm{H}), 7.38(\mathrm{~d}, J=2.0 \mathrm{~Hz}, 1 \mathrm{H}), 7.54(\mathrm{dd}, J=8.4,2.0 \mathrm{~Hz}, 1 \mathrm{H}) .{ }^{13} \mathrm{C}-\mathrm{NMR}\left(d_{6}\right.$-DMSO, $\left.101 \mathrm{MHz}\right) \delta$ (ppm): 21.42, 22.15, 22.31, 28.08, 55.90, 56.15, 62.11, 62.95, 111.40, 112.02, 122.25, 123.55, 139.51, 148.76, 
149.47, 150.16, 153.34, 154.77, 165.89, 165.92. ESI-HRMS Calcd. for $\mathrm{C}_{20} \mathrm{H}_{24} \mathrm{~N}_{2} \mathrm{O}_{6}[\mathrm{M}+\mathrm{Na}]^{+}$: 411.1527; found: 411.1528 .

3-[(2,6-Dimethoxybenzoyl)oxy]propyl 3,5,6-trimethylpyrazine-2-carboxylate (8e). Compound $\mathbf{6}$ was treated with 2,6-dimethoxybenzoic acid (7e) according to general procedure to give the desired product $8 \mathbf{e}$ as a white solid. Yield 51\%, ${ }^{1} \mathrm{H}-\mathrm{NMR}\left(\mathrm{CDCl}_{3}, 300 \mathrm{MHz}\right) \delta(\mathrm{ppm}): 2.25(\mathrm{~m}, 2 \mathrm{H}), 2.56(\mathrm{~s}, 6 \mathrm{H}), 2.73(\mathrm{~s}, 3 \mathrm{H})$, $3.81(\mathrm{~s}, 6 \mathrm{H}), 4.49(\mathrm{t}, J=6.1 \mathrm{~Hz}, 2 \mathrm{H}), 4.55(\mathrm{t}, J=6.5 \mathrm{~Hz}, 2 \mathrm{H}), 6.54(\mathrm{~d}, J=8.4 \mathrm{~Hz}, 2 \mathrm{H}), 7.27(\mathrm{t}, J=8.4 \mathrm{~Hz}$, 1H). ${ }^{13} \mathrm{C}-\mathrm{NMR}\left(\mathrm{CDCl}_{3}, 75 \mathrm{MHz}\right) \delta 21.54,22.14,22.55,27.99,55.94,61.59,62.53,103.83,112.82,131.15$, $139.59,149.27,150.93,154.39,157.33,165.99,166.42$. ESI-HRMS Calcd. for $\mathrm{C}_{20} \mathrm{H}_{24} \mathrm{~N}_{2} \mathrm{O}_{6}[\mathrm{M}+\mathrm{Na}]^{+}$: 411.1527; found: 411.1526 .

3-[(3-Chlorobenzoyl)oxy]propyl 3,5,6-trimethylpyrazine-2-carboxylate (8f). Compound $\mathbf{6}$ was treated with 3-chlorobenzoic acid (7f) according to general procedure to give the desired product $\mathbf{8 f}$ as a white solid. Yield 51\%, ${ }^{1} \mathrm{H}-\mathrm{NMR}\left(\mathrm{CDCl}_{3}, 300 \mathrm{MHz}\right) \delta(\mathrm{ppm}): 2.30(\mathrm{~m}, 2 \mathrm{H}), 2.53(\mathrm{~s}, 3 \mathrm{H}), 2.55(\mathrm{~s}, 3 \mathrm{H}), 2.72(\mathrm{~s}, 3 \mathrm{H})$, $4.49(\mathrm{t}, J=6.2 \mathrm{~Hz}, 2 \mathrm{H}), 4.57(\mathrm{t}, J=6.4 \mathrm{~Hz}, 2 \mathrm{H}), 7.34(\mathrm{t}, J=7.9 \mathrm{~Hz}, 1 \mathrm{H}), 7.50(\mathrm{ddd}, J=8.0,2.2,1.1 \mathrm{~Hz}, 1 \mathrm{H})$, $7.88(\mathrm{dt}, J=7.7,1.3 \mathrm{~Hz}, 1 \mathrm{H}), 7.95(\mathrm{t}, J=1.8 \mathrm{~Hz}, 1 \mathrm{H}) .{ }^{13} \mathrm{C}-\mathrm{NMR}\left(\mathrm{CDCl}_{3}, 75 \mathrm{MHz}\right) \delta(\mathrm{ppm}): 21.54,22.16$, 22.57, 28.04, 62.17, 62.55, 127.66, 129.61 (d, $J=7.1 \mathrm{~Hz}$ ), 131.73, 132.96, 134.44, 139.21, 149.27, 151.21, 154.56, 165.19, 165.84. ESI-HRMS Calcd. for $\mathrm{C}_{18} \mathrm{H}_{19} \mathrm{~N}_{2} \mathrm{O}_{4} \mathrm{Cl}[\mathrm{M}+\mathrm{Na}]^{+}$: 385.0926; found: 385.0936.

3-[(3-Bromobenzoyl)oxy]propyl 3,5,6-trimethylpyrazine-2-carboxylate (8g). Compound $\mathbf{6}$ was treated with 3-bromobenzoic acid $(\mathbf{7 g})$ according to general procedure to give the desired product $8 \mathbf{g}$ as a white solid. Yield 42\%, ${ }^{1} \mathrm{H}-\mathrm{NMR}\left(d_{6}\right.$-DMSO, $\left.400 \mathrm{MHz}\right) \delta(\mathrm{ppm}): 2.19(\mathrm{~m}, 2 \mathrm{H}), 2.41(\mathrm{~s}, 3 \mathrm{H}), 2.47(\mathrm{~s}, 3 \mathrm{H}), 2.56(\mathrm{~s}$, $3 \mathrm{H}), 4.43(\mathrm{t}, J=5.9 \mathrm{~Hz}, 2 \mathrm{H}), 4.48(\mathrm{t}, J=6.0 \mathrm{~Hz}, 2 \mathrm{H}), 7.43(\mathrm{t}, J=7.3 \mathrm{~Hz}, 1 \mathrm{H}), 7.81(\mathrm{~d}, J=7.9 \mathrm{~Hz}, 1 \mathrm{H}), 7.94$ $(\mathrm{d}, J=7.6 \mathrm{~Hz}, 1 \mathrm{H}), 8.04(\mathrm{~s}, 1 \mathrm{H}) .{ }^{13} \mathrm{C}-\mathrm{NMR}\left(d_{6}\right.$-DMSO, $\left.101 \mathrm{MHz}\right) \delta(\mathrm{ppm}): 165.83,164.89,150.22,139.35$, $138.38,136.39,132.50,131.92,131.45,131.26,128.55,122.25,63.02,57.68,31.86,27.88,22.29,22.14,21.40$. ESI-HRMS Calcd. for $\mathrm{C}_{18} \mathrm{H}_{19} \mathrm{~N}_{2} \mathrm{O}_{4} \mathrm{Br}[\mathrm{M}+\mathrm{H}]^{+}$: 407.0601; found: 407.0605.

3-[(4-Bromobenzoyl)oxy]propyl 3,5,6-trimethylpyrazine-2-carboxylate (8h). Compound $\mathbf{6}$ was treated with 4-bromobenzoic acid ( $7 \mathrm{~h})$ according to general procedure to give the desired product $8 \mathrm{~h}$ as a white solid. Yield 42\%, ${ }^{1} \mathrm{H}-\mathrm{NMR}\left(d_{6}\right.$-DMSO, $\left.400 \mathrm{MHz}\right) \delta(\mathrm{ppm}): 2.19(\mathrm{~m}, 2 \mathrm{H}), 2.43(\mathrm{~s}, 3 \mathrm{H}), 2.49(\mathrm{~s}, 3 \mathrm{H}), 2.57$ $(\mathrm{s}, 3 \mathrm{H}), 4.42(\mathrm{t}, J=6.0 \mathrm{~Hz}, 2 \mathrm{H}), 4.47(\mathrm{t}, J=6.2 \mathrm{~Hz}, 2 \mathrm{H}), 7.66(\mathrm{~d}, J=8.5 \mathrm{~Hz}, 2 \mathrm{H}), 7.81(\mathrm{~d}, J=8.5 \mathrm{~Hz}, 2 \mathrm{H})$. ${ }^{13} \mathrm{C}-\mathrm{NMR}\left(d_{6}\right.$-DMSO, $\left.101 \mathrm{MHz}\right) \delta(\mathrm{ppm}): 21.43,22.21,22.32,27.92,31.93,57.68,62.80,63.01,127.74$, 129.26, 131.48, 132.18, 139.45, 149.48, 154.81, 165.46, 165.90. ESI-HRMS Calcd. for $\mathrm{C}_{18} \mathrm{H}_{19} \mathrm{~N}_{2} \mathrm{O}_{4} \mathrm{Br}$ $[\mathrm{M}+\mathrm{H}]^{+}:$407.0601; found: 407.0616.

3-[(4-Fluorobenzoyl)oxy]propyl 3,5,6-trimethylpyrazine-2-carboxylate (8i). Compound $\mathbf{6}$ was treated with 4-fluorobenzoic acid (7i) according to general procedure to give the desired product $8 \mathbf{i}$ as a white solid. Yield 42\%, ${ }^{1} \mathrm{H}-\mathrm{NMR}\left(d_{6}\right.$-DMSO, $\left.400 \mathrm{MHz}\right) \delta(\mathrm{ppm}): 2.19(\mathrm{~m}, 2 \mathrm{H}), 2.44(\mathrm{~s}, 3 \mathrm{H}), 2.49(\mathrm{~s}, 3 \mathrm{H}), 2.57(\mathrm{~s}, 3 \mathrm{H})$, $4.41(\mathrm{t}, J=6.1 \mathrm{~Hz}, 2 \mathrm{H}), 4.48(\mathrm{t}, J=6.2 \mathrm{~Hz}, 2 \mathrm{H}), 7.29(\mathrm{t}, J=8.8 \mathrm{~Hz}, 2 \mathrm{H}), 7.98(\mathrm{dd}, J=8.8,5.6 \mathrm{~Hz}, 1 \mathrm{H})$. ${ }^{13} \mathrm{C}$-NMR $\left(d_{6}\right.$-DMSO, $\left.101 \mathrm{MHz}\right) \delta(\mathrm{ppm}): 21.44,22.17,22.30,27.97,31.98,57.70,62.56,62.92,116.08$, $116.30,132.39,132.48,139.48,149.52,150.20,154.82,165.21,165.92$. ESI-HRMS Calcd. for $\mathrm{C}_{18} \mathrm{H}_{19} \mathrm{~N}_{2} \mathrm{O}_{4} \mathrm{~F}$ $[\mathrm{M}+\mathrm{H}]^{+}:$347.1402; found: 347.1411 .

3-[(3-Fluoro-4-methoxybenzoyl)oxy]propyl 3,5,6-trimethylpyrazine-2-carboxylate (8j). Compound $\mathbf{6}$ was treated with 3-fluoro-4-methoxybenzoic acid (7j) according to general procedure to give the desired product $8 \mathbf{j}$ as a white solid. Yield $43 \%,{ }^{1} \mathrm{H}-\mathrm{NMR}\left(d_{6}-\mathrm{DMSO}, 400 \mathrm{MHz}\right) \delta(\mathrm{ppm}): 2.18(\mathrm{~m}, 2 \mathrm{H}), 2.44$ $(\mathrm{s}, 3 \mathrm{H}), 2.48(\mathrm{~s}, 3 \mathrm{H}), 2.57(\mathrm{~s}, 3 \mathrm{H}), 3.91(\mathrm{~s}, 3 \mathrm{H}), 4.39(\mathrm{t}, J=6.0 \mathrm{~Hz}, 2 \mathrm{H}), 4.47(\mathrm{t}, J=6.2 \mathrm{~Hz}, 2 \mathrm{H}), 7.22(\mathrm{t}$, $J=8.6 \mathrm{~Hz}, 1 \mathrm{H}), 7.61(\mathrm{dd}, J=11.9,2.1 \mathrm{~Hz}, 1 \mathrm{H}), 7.74(\mathrm{ddd}, J=8.6,2.1,1.2 \mathrm{~Hz}, 1 \mathrm{H}) .{ }^{13} \mathrm{C}-\mathrm{NMR}\left(d_{6}\right.$-DMSO, $101 \mathrm{MHz}$ ) $\delta$ (ppm): 21.42, 22.15, 22.30, 27.98, 56.77, 62.55, 63.03, 113.81, 116.55, 116.75, 122.53, 122.59, 127.14, 127.17, 139.48, 149.48, 150.18, 151.68, 151.78, 152.42, 154.77, 164.99, 165.91. ESI-HRMS Calcd. for $\mathrm{C}_{19} \mathrm{H}_{21} \mathrm{~N}_{2} \mathrm{O}_{7} \mathrm{~F}[\mathrm{M}+\mathrm{H}]^{+}$: 377.1507; found: 377.1515.

3-[(3-Fluorobenzoyl)oxy]propyl 3,5,6-trimethylpyrazine-2-carboxylate (8k). Compound $\mathbf{6}$ was treated with 3-fluoro-4-methoxybenzoic acid (7k) according to general procedure to give the desired product $\mathbf{8 k}$ 
as a white solid. Yield $48 \%,{ }^{1} \mathrm{H}-\mathrm{NMR}\left(\mathrm{CDCl}_{3}, 300 \mathrm{MHz}\right) \delta(\mathrm{ppm}): 2.30(\mathrm{~m}, 2 \mathrm{H}), 2.53(\mathrm{~s}, 3 \mathrm{H}), 2.55$ (s, $3 \mathrm{H}), 2.72(\mathrm{~s}, 3 \mathrm{H}), 4.49(\mathrm{t}, J=6.1 \mathrm{~Hz}, 2 \mathrm{H}), 4.57(\mathrm{t}, J=6.3 \mathrm{~Hz}, 2 \mathrm{H}), 7.34(\mathrm{t}, J=7.9 \mathrm{~Hz}, 1 \mathrm{H}), 7.50(\mathrm{ddd}$, $J=8.0,2.2,1.1 \mathrm{~Hz}, 1 \mathrm{H}), 7.88(\mathrm{dt}, J=7.7,1.4 \mathrm{~Hz}, 1 \mathrm{H}), 7.95(\mathrm{t}, J=1.9 \mathrm{~Hz}, 1 \mathrm{H}) .{ }^{13} \mathrm{C}-\mathrm{NMR}\left(d_{6}\right.$-DMSO, $101 \mathrm{MHz}) \delta$ (ppm): 164.69, 162.86, 160.42, 154.07, 149.95, 148.81, 138.20, 129.30, 129.22, 124.15, 118.86, $114.83,62.00,61.66,26.84,20.22,19.70,18.84$. ESI-HRMS Calcd. for $\mathrm{C}_{18} \mathrm{H}_{19} \mathrm{~N}_{2} \mathrm{O}_{4} \mathrm{~F}[\mathrm{M}+\mathrm{Na}]^{+}: 369.1221$; found: 369.1231 .

3-\{[(3,4,5-Trimethoxyphenyl)acetyl]oxy\}propyl 3,5,6-trimethylpyrazine-2-carboxylate (81). Compound 6 was treated with (3,4,5-trimethoxyphenyl)acetic acid (7l) according to general procedure to give the desired product 81 as a white solid. Yield 43\%, ${ }^{1} \mathrm{H}-\mathrm{NMR}\left(\mathrm{CDCl}_{3}, 300 \mathrm{MHz}\right) \delta(\mathrm{ppm}): 2.17(\mathrm{~m}, 2 \mathrm{H}), 2.57(\mathrm{~s}$, $6 \mathrm{H}), 2.73(\mathrm{~s}, 3 \mathrm{H}), 3.57(\mathrm{~s}, 2 \mathrm{H}), 3.83(\mathrm{~s}, 3 \mathrm{H}), 3.86(\mathrm{~s}, 6 \mathrm{H}), 4.27(\mathrm{t}, J=6.2 \mathrm{~Hz}, 2 \mathrm{H}), 4.48(\mathrm{t}, J=6.5 \mathrm{~Hz}, 2 \mathrm{H})$, $6.51(\mathrm{~s}, 2 \mathrm{H}) .{ }^{13} \mathrm{C}-\mathrm{NMR}\left(\mathrm{CDCl}_{3}, 75 \mathrm{MHz}\right) \delta(\mathrm{ppm}): 21.55,22.16,22.54,27.95,41.46,56.06,60.79,61.48$, $62.28,106.23,129.37,137.04,139.27,149.29,151.14,153.20,154.60,165.84,171.44$. ESI-HRMS Calcd. for $\mathrm{C}_{22} \mathrm{H}_{28} \mathrm{~N}_{2} \mathrm{O}_{7}[\mathrm{M}+\mathrm{Na}]^{+}$: 455.1789; found: 455.1783 .

3-\{[(4-Bromophenyl)acetyl]oxy\}propyl 3,5,6-trimethylpyrazine-2-carboxylate (8m). Compound 6 was treated with (4-bromophenyl)acetic acid $(7 \mathbf{m})$ according to general procedure to give the desired product $8 \mathbf{m}$ as a white solid. Yield $47 \%,{ }^{1} \mathrm{H}-\mathrm{NMR}\left(d_{6}\right.$-DMSO, $\left.400 \mathrm{MHz}\right) \delta(\mathrm{ppm}): 2.04(\mathrm{~m}, 2 \mathrm{H}), 2.47(\mathrm{~s}, 3 \mathrm{H}), 2.51(\mathrm{~s}$, $3 \mathrm{H}), 2.59(\mathrm{~s}, 3 \mathrm{H}), 3.68(\mathrm{~s}, 2 \mathrm{H}), 4.17(\mathrm{t}, J=6.3 \mathrm{~Hz}, 1 \mathrm{H}), 4.35(\mathrm{t}, J=6.4 \mathrm{~Hz}, 1 \mathrm{H}), 7.22(\mathrm{~d}, J=8.4 \mathrm{~Hz}, 2 \mathrm{H}), 7.49$ $(\mathrm{d}, J=8.4 \mathrm{~Hz}, 2 \mathrm{H}) .{ }^{13} \mathrm{C}-\mathrm{NMR}\left(d_{6}\right.$-DMSO, $\left.101 \mathrm{MHz}\right) \delta(\mathrm{ppm}): 21.48,22.22,22.31,27.93,31.94,57.62,61.77$, $62.50,120.49,131.62,132.10,134.26,134.40,139.54,149.60,150.18,154.89,165.90,171.26$. ESI-HRMS Calcd. for $\mathrm{C}_{19} \mathrm{H}_{21} \mathrm{~N}_{2} \mathrm{O}_{4} \mathrm{Br}[\mathrm{M}+\mathrm{H}]^{+}$: 443.0577; found: 443.0581 .

3-\{[(3-Fluoro-4-methoxyphenyl)acetyl]oxy\}propyl 3,5,6-trimethylpyrazine-2-carboxylate (8n). Compound $\mathbf{6}$ was treated with (3-fluoro-4-methoxyphenyl)acetic acid (7n) according to general procedure to give the desired product $8 \mathbf{n}$ as a white solid. Yield $47 \% .{ }^{1} \mathrm{H}-\mathrm{NMR}\left(d_{6}\right.$-DMSO, $\left.400 \mathrm{MHz}\right) \delta(\mathrm{ppm}): 6.86(\mathrm{~d}$, $J=7.6 \mathrm{~Hz}, 1 \mathrm{H}), 6.67(\mathrm{~d}, J=9.6 \mathrm{~Hz}, 1 \mathrm{H}), 6.41(\mathrm{t}, J=8.5 \mathrm{~Hz}, 1 \mathrm{H}), 3.67(\mathrm{t}, J=6.1 \mathrm{~Hz}, 3 \mathrm{H}), 3.60(\mathrm{t}, J=6.1 \mathrm{~Hz}$, $3 \mathrm{H}), 2.42(\mathrm{~s}, 2 \mathrm{H}), 1.75(\mathrm{~s}, 3 \mathrm{H}), 1.63(\mathrm{~s}, 3 \mathrm{H}), 1.59(\mathrm{~s}, 3 \mathrm{H}), 1.37-1.43(\mathrm{~m}, 2 \mathrm{H}) .{ }^{13} \mathrm{C}-\mathrm{NMR}\left(d_{6}\right.$-DMSO, 101 MHz) $\delta$ (ppm): 18.88, 19.73, 20.23, 26.74, 38.58, 54.50, 60.53, 61.33, 112.46, 115.53, 115.71, 124.09, 126.24, 126.31, 138.27, 148.89, 149.92, 154.13, 164.72, 170.97. ESI-HRMS Calcd. for $\mathrm{C}_{20} \mathrm{H}_{23} \mathrm{~N}_{2} \mathrm{O}_{5} \mathrm{~F}[\mathrm{M}+\mathrm{H}]^{+}$: 413.1483; found: 413.1484 .

3-\{[(2E)-3-(3,4-Dimethoxyphenyl)prop-2-enoyl]oxy\}propyl 3,5,6-trimethyl-pyrazine-2-carboxylate (8o). Compound 6 was treated with (2E)-3-(3,4-dimethoxyphenyl)prop-2-enoic acid (7o) according to general procedure to give the desired product 80 as a white solid. Yield $53 \%,{ }^{1} \mathrm{H}-\mathrm{NMR}\left(d_{6}\right.$-DMSO, 400 MHz) $\delta(\mathrm{ppm}): 2.12(\mathrm{~m}, 2 \mathrm{H}), 2.45(\mathrm{~s}, 3 \mathrm{H}), 2.46(\mathrm{~s}, 3 \mathrm{H}), 2.61(\mathrm{~s}, 3 \mathrm{H}), 3.79(\mathrm{~s}, 3 \mathrm{H}), 3.80(\mathrm{~s}, 3 \mathrm{H}), 4.28(\mathrm{t}$, $J=6.2 \mathrm{~Hz}, 2 \mathrm{H}), 4.43(\mathrm{t}, J=6.3 \mathrm{~Hz}, 2 \mathrm{H}), 6.50(\mathrm{~d}, J=15.9 \mathrm{~Hz}, 1 \mathrm{H}), 6.98(\mathrm{~d}, J=8.3 \mathrm{~Hz}, 1 \mathrm{H}), 7.18(\mathrm{dd}$, $J=8.3,2.0 \mathrm{~Hz}, 1 \mathrm{H}), 7.30(\mathrm{~d}, J=1.9 \mathrm{~Hz}, 1 \mathrm{H}), 7.54(\mathrm{~d}, J=15.9 \mathrm{~Hz}, 1 \mathrm{H}) .{ }^{13} \mathrm{C}-\mathrm{NMR}\left(d_{6}-\mathrm{DMSO}, 101 \mathrm{MHz}\right) \delta$ (ppm): 21.47, 22.16, 22.34, 28.11, 56.04, 56.06, 61.41, 62.83, 110.72, 111.93, 115.77, 123.43, 127.24, 139.54, $145.20,149.41,149.55,150.20,151.45,154.83,165.94,166.94$. ESI-HRMS Calcd. for $\mathrm{C}_{22} \mathrm{H}_{26} \mathrm{~N}_{2} \mathrm{O}_{6}[\mathrm{M}+$ $\mathrm{Na}]^{+}: 437.1683$; found: 437.1686 .

3-\{[(2E)-3-(3,4,5-Trimethoxyphenyl)prop-2-enoyl]oxy\}propyl 3,5,6-tri-methylpyrazine-2-carboxylate (8p). Compound 6 was treated with (2E)-3-(3,4,5-trimethoxyphenyl)prop-2-enoic acid (7p) according to general procedure to give the desired product $8 \mathrm{p}$ as a white solid. Yield $53 \%,{ }^{1} \mathrm{H}-\mathrm{NMR}\left(\mathrm{CDCl}_{3}\right.$, $300 \mathrm{MHz}$ ) $\delta(\mathrm{ppm}): 2.18-2.25(\mathrm{~m}, 2 \mathrm{H}), 2.53(\mathrm{~s}, 6 \mathrm{H}), 2.73(\mathrm{~s}, 3 \mathrm{H}), 3.88(\mathrm{~s}, 9 \mathrm{H}), 4.34-4.38(\mathrm{t}, J=6.2 \mathrm{~Hz}, 2 \mathrm{H})$, $4.52-4.56(\mathrm{t}, J=6.4 \mathrm{~Hz}, 2 \mathrm{H}), 6.31(\mathrm{~d}, J=15.9 \mathrm{~Hz}, 1 \mathrm{H}), 6.72(\mathrm{~s}, 2 \mathrm{H}), 7.56(\mathrm{~d}, J=15.9 \mathrm{~Hz}, 1 \mathrm{H}) .{ }^{13} \mathrm{C}-\mathrm{NMR}$ $\left(d_{6}\right.$-DMSO, $\left.101 \mathrm{MHz}\right) \delta$ (ppm): 21.46, 22.15, 22.36, 28.08, 32.11, 56.51, 57.76, 60.56, 61.55, 61.83, 62.83, $106.41,117.60,117.89,130.11,139.91,145.09,145.23,149.57,153.52,154.85,165.96,166.93$. ESI- HRMS Calcd. for $\mathrm{C}_{23} \mathrm{H}_{28} \mathrm{~N}_{2} \mathrm{O}_{7}[\mathrm{M}+\mathrm{Na}]^{+}$: 467.1789; found: 467.1759.

3-\{[(2E)-3-(3,5,6-Trimethylpyrazin-2-yl)prop-2-enoyl]oxy\}propyl 3,5,6-trimethylpyrazine-2-carboxylate (8q). Compound 6 was treated with (2E)-3-(3,5,6-trimethylpyrazin-2-yl)prop-2-enoic acid (7q) according to general procedure to give the desired product $8 \mathbf{q}$ as a white solid. Yield $53 \%,{ }^{1} \mathrm{H}-\mathrm{NMR}\left(\mathrm{CDCl}_{3}\right.$, 
$300 \mathrm{MHz},) \delta(\mathrm{ppm}): 2.22(\mathrm{~m}, 2 \mathrm{H}), 2.54-2.50(\mathrm{~m}, 12 \mathrm{H}), 2.59(\mathrm{~s}, 3 \mathrm{H}), 2.73(\mathrm{~s}, 3 \mathrm{H}), 4.37(\mathrm{t}, J=6.2 \mathrm{~Hz}, 2 \mathrm{H})$, $4.53(\mathrm{t}, J=6.4 \mathrm{~Hz}, 2 \mathrm{H}), 7.02(\mathrm{~d}, J=15.3 \mathrm{~Hz}, 1 \mathrm{H}), 7.83(\mathrm{~d}, J=15.3 \mathrm{~Hz}, 1 \mathrm{H}) .{ }^{13} \mathrm{C}-\mathrm{NMR}\left(\mathrm{CDCl}_{3}, 126 \mathrm{MHz}\right) \delta$ (ppm): 166.84,166.53, 165.64, 154.41, 152.49, 151.02, 149.84, 149.20, 148.70, 142.38, 138.70, 122.75, 61.58, $58.45,31.61,22.41,21.95,21.76,21.55,21.34,20.43$. ESI-HRMS Calcd. for $\mathrm{C}_{21} \mathrm{H}_{26} \mathrm{~N}_{4} \mathrm{O}_{4}[\mathrm{M}+\mathrm{Na}]^{+}$: 421.1846; found: 421.1848 .

3-[(Pyridine-2-carbonyl)oxy]propyl 3,5,6-trimethylpyrazine-2-carboxylate (8r). Compound 6 was treated with pyridine-2-carboxylic acid (7r) according to general procedure to give the desired product $8 \mathbf{r}$ as a white solid. Yield 53\%, ${ }^{1} \mathrm{H}-\mathrm{NMR}\left(\mathrm{CDCl}_{3}, 300 \mathrm{MHz}\right) \delta(\mathrm{ppm}): 2.31(\mathrm{~m}, 2 \mathrm{H}), 2.54(\mathrm{~s}, 3 \mathrm{H}), 2.55(\mathrm{~s}, 3 \mathrm{H})$, $2.73(\mathrm{~s}, 3 \mathrm{H}), 4.52(\mathrm{t}, J=6.2 \mathrm{~Hz}, 2 \mathrm{H}), 4.57(\mathrm{t}, J=6.3 \mathrm{~Hz}, 2 \mathrm{H}), 7.37(\mathrm{dd}, J=8.0,4.9 \mathrm{~Hz}, 1 \mathrm{H}), 8.27(\mathrm{dt}, J=8.0$, $1.9 \mathrm{~Hz}, 1 \mathrm{H}), 8.76(\mathrm{dd}, J=4.8,1.6 \mathrm{~Hz}, 1 \mathrm{H}), 9.19(\mathrm{~d}, J=1.9 \mathrm{~Hz}, 1 \mathrm{H}) .{ }^{13} \mathrm{C}-\mathrm{NMR}\left(\mathrm{CDCl}_{3}, 75 \mathrm{MHz}\right) \delta(\mathrm{ppm})$ : 21.55, 22.17, 22.56, 28.04, 62.27 (d, $J=17.9 \mathrm{~Hz}), 123.26,125.91,137.00,139.18,149.29,150.86,151.23$, 153.44, 154.62, 165.12, 165.84. ESI-HRMS Calcd. for $\mathrm{C}_{17} \mathrm{H}_{19} \mathrm{~N}_{3} \mathrm{O}_{4}[\mathrm{M}+\mathrm{Na}]^{+}:$352.1268; found: 352.1271 .

\subsection{Biological Activity}

\subsubsection{Inhibitory Activities of AChE and BuChE}

Acetylcholinesterase (AChE, E.C. 3.1.1.7, from electric eel), butyrylcholinesterase (BuChE, E.C. 3.1.1.8, from equine serum), acetylthiocholine chloride (ATC), butyrylthiocholine chloride (BTC), and 5,5'-dithiobis-(2-nitrobenzoic acid) (Ellman's reagent, DTNB) were purchased from Merck \& Co. Tacrine hydrochloride (Darmstadt, Germany) and galanthamine hydrobromide were used as the reference and purchased from Sigma-Aldrich (Santa Clara, CA. USA,). Photometric 96-well microplates made from polystyrene (Thermo Scientific, Waltham, CA. USA) were used for measurement purposes.

AChE and BuChE inhibitory activities were measured by the spectrophotometric method of Ellman, with slight modification [29]. Briefly, all in vitro assays were performed in $0.1 \mathrm{M}$ $\mathrm{NaH}_{2} \mathrm{PO}_{4} / \mathrm{Na}_{2} \mathrm{HPO}_{4}$ buffer, pH 7.4, using a THERMO Enzyme-labeled Instrument. The enzyme solutions were prepared to obtain 2.0 units $/ \mathrm{mL}$ in $2.0 \mathrm{~mL}$ aliquots. The assay medium $(1 \mathrm{~mL})$ consisted of phosphate buffer ( $\mathrm{pH} 7.4$ ), $10 \mu \mathrm{L}$ of the enzyme, $30 \mu \mathrm{L}$ of $0.01 \mathrm{M}$ DTNB, and $30 \mu \mathrm{L}$ of substrate (ATC or BTC) at a concentration of $0.01 \mathrm{M}$. The test and reference compounds were first dissolved in DMSO (5\%) and fetal bovine serum (1\%o), and then diluted in $0.1 \mathrm{M} \mathrm{NaH}_{2} \mathrm{PO}_{4} / \mathrm{Na}_{2} \mathrm{HPO}_{4}$ buffer ( $\mathrm{pH}$ 7.4) to provide a final concentration range. The inhibitors were added to the assay solution containing enzyme, buffer, and DTNB with pre-incubation for $20 \mathrm{~min}$ at $37^{\circ} \mathrm{C}$, prior to the addition of the substrate. The activity was determined by measuring the increase in absorbance at $410 \mathrm{~nm}$ at $1 \mathrm{~min}$ intervals at $37^{\circ} \mathrm{C}$. The data were calculated according to the method described by Ellman et al. Each concentration was assayed in triplicate. Blanks containing all of the components except AChE were included in the analyses.

\subsubsection{Inhibition of Self-Mediated A $\beta$ (1-42) Aggregation}

A Thioflavin T-based fluorometric assay was performed in order to investigate the self-induced A $\beta$ (1-42) aggregation [27]. Briefly, compounds to be tested were firstly dissolved in DMSO to obtain a $10 \mathrm{mM}$ solution and then diluted in phosphate buffer $(\mathrm{pH} 7.4)$ to provide a final concentration range. $\mathrm{A} \beta$ (1-42) peptide (Sigma-Aldrich) was prepared in $10 \mathrm{mM}$ phosphate buffer ( $\mathrm{pH} 7.4$ ) to give a final concentration of $20 \mu \mathrm{M}$ solution and incubated at $37^{\circ} \mathrm{C}$ for $24 \mathrm{~h}$ with the inhibitors at different concentrations $(0,5,10,20,50,100,150,200,250,300 \mu \mathrm{M})$. After incubation, thioflavin-T $(5 \mu \mathrm{M}$ in $50 \mathrm{mM}$ glycine-NaOH buffer, $\mathrm{pH} 8.0$ ) was added into the above 96-well microplate and the samples were diluted to a final volume of $150 \mu \mathrm{L}$. Fluorescence was measured at $450 \mathrm{~nm}(\lambda \mathrm{ex})$ and $485 \mathrm{~nm}$ ( $\lambda$ em) on a Varioskan Flash Multimode Reader (Thermo Scientific). Each inhibitor was run in triplicate.

\subsubsection{Transmission Electron Microscopy (TEM) Assay}

A $\beta$ (1-42) peptide (Sigma-Aldrich) was added into a 96-well microplate and then diluted by phosphate buffer (10 mM, pH 7.4) to provide a concentration of $100 \mu \mathrm{M}$ solution at $4{ }^{\circ} \mathrm{C}$ before use and 
the sample preparation procedure was the same as that used for the Thioflavin T assay. Aliquots $(5 \mu \mathrm{L})$ of the samples were placed on a carbon-coated copper/rhodium grid for 2 min at room temperature. Each grid was stained with phosphomolybdic acid solution $(3 \%, 5 \mu \mathrm{L})$ for $2 \mathrm{~min}$. After draining off the excess staining solution, the specimen was transferred for imaging by transmission electron microscopy.

\subsubsection{Kinetic Study of AChE Inhibition}

The assay solution $(100 \mu \mathrm{L})$ was afforded by the addition of $30 \mu \mathrm{L}$ of DTNB $(0.01 \mathrm{M}), 10 \mu \mathrm{L}$ of 2 units $/ \mathrm{mL}$ AChE, and $30 \mu \mathrm{L}$ of substrate (ATC) to the phosphate buffer (0.1 M, pH 7.0). Three different concentrations of $\mathbf{8 q}$ were added to the assay solution with the AChE and pre-incubated for 20 min at $37^{\circ} \mathrm{C}$, followed by the addition of substrate in different concentrations. Kinetic characterization of the hydrolysis of ATC catalysed by AChE was carried out at $410 \mathrm{~nm}$. A parallel control was made with the assay solution of no inhibitor for each time. The plots were assessed by a weighted least square analysis that assumed the variance of $\mathrm{V}$ to be a constant percentage of $\mathrm{V}$ for the entire data set. Slopes of these reciprocal plots were then plotted against the concentration of $\mathbf{8 q}$ in a weighted analysis, and $\mathrm{Km}$ was determined as the intercept on the negative $\mathrm{x}$-axis.

\subsubsection{In Vitro Cytotoxicity of Tacrine and Ligustrazine Hybrids 8q, 8r in HepG2 Cells}

HepG2 cells (human hepatocellular liver carcinoma cell line from American Type Culture Collection, ATCC) were cultured in Eagle's minimum essential medium (EMEM) supplemented with $10 \%$ heat-inactivated fetal bovine serum (FBS), and $100 \mathrm{U} / \mathrm{mL}$ of penicillin/streptomycin (Gino Biomedical Technology Co. LTD., Hangzhou, China). Cultures were seeded into flasks containing supplemented medium and maintained at $37{ }^{\circ} \mathrm{C}$ in a humidified atmosphere of $5 \% \mathrm{CO}_{2}$. For assays, cells $\left(1.0 \times 10^{5}\right.$ cells/well $)$ were seeded in a 96-well plate in complete medium, the medium was removed after $24 \mathrm{~h}$, and cells were exposed to the increasing concentrations of compounds $8 \mathbf{q}$ or $8 \mathbf{r}(0$, $25,50,125,200,300,400$, and $500 \mu \mathrm{M}$ ) in DMEM with no serum for a further $24 \mathrm{~h}$. Cell survival was measured through a CCK-8 assay. All compounds were dissolved in pure DMSO.

\subsubsection{In Vitro Cytotoxicity of Tacrine and Compounds $\mathbf{8 q}$, 8r in SH-SY5Y Cells}

SH-SY5Y cells (human neuroblastoma cell line from American Type Culture Collection, ATCC, Manassas, VA, USA) were seeded into 96-well plates at a density of $4 \times 10^{4}$ cells $/ \mathrm{mL}$ in Dulbecco's modified Eagle's medium (DMEM) supplemented with 10\% FBS and $100 \mathrm{U} / \mathrm{mL}$ of penicillin/streptomycin (Gino Biomedical Technology Co. LTD., Hangzhou, China), and incubated in a humidified atmosphere containing $5 \% \mathrm{CO}_{2}$ at $37^{\circ} \mathrm{C}$. For the experiments, cells $(1.0 \times 105$ cells $/$ well $)$ were seeded in a 96-well plate in complete medium; after $24 \mathrm{~h}$, cells were treated with the test compound in different concentrations $(0,25,50,125,200,300,400$, and $500 \mu \mathrm{M})$ at $37^{\circ} \mathrm{C}$ for $24 \mathrm{~h}$. After this incubation, $10 \mu \mathrm{L} /$ well of CCK-8 $(5 \mathrm{mg} / \mathrm{mL})$ was added and incubated at $37{ }^{\circ} \mathrm{C}$ for $4 \mathrm{~h}$. The optical density (OD) of each well was measured using an Epoch Microplate Spectrophotometer (BioTek Instruments, Inc., Winooski, VT, USA) with a test wavelength of 450, $630 \mathrm{~nm}$.

\subsection{Molecular Docking}

For the docking studies, the Surflex dock in Sybyl X-2.1.1 (Certara, L.P., Princeton, NJ, USA) was used. The structures of $\mathbf{8 q}$ and $\mathbf{8 r}$ were built in Sybyl and the energy was minimized with the conjugate gradient method. For the protein, all the water molecules were extracted and the AMBER FF99 force field was applied. The standard docking procedure was used with the parameters set in default. Re-docking the original ligand into the crystal structure was performed to test the reliability of the docking strategy. Binding modes and interactions were analyzed in Pymol. 


\section{Conclusions}

In summary, a series of novel ligustrazine derivatives $8 \mathbf{a}-8 \mathbf{r}$ have been designed, synthesized, and evaluated for the first time as multi-targeted inhibitors for anti-AD drug discovery. The results demonstrated that: (1) most of the target compounds exhibited potent AChE inhibitory activities, even at a nanomolar level, with excellent selectivity towards AChE. In particular, compounds $\mathbf{8 q}$ and $8 \mathbf{r}$ were found to be the most active inhibitors against $\mathrm{AChE}$, with $\mathrm{IC}_{50}$ values of 1.39 and $0.25 \mathrm{nM}$, respectively, and the highest selectivity for $\mathrm{AChE}$ (for $\mathbf{8 q}, \mathrm{IC}_{50} \mathrm{BuChE} / \mathrm{IC}_{50} \mathrm{AChE}=2.91 \times 10^{6}$; for 8r, $\mathrm{IC}_{50} \mathrm{BuChE} / \mathrm{IC}_{50} \mathrm{AChE}=1.32 \times 10^{7}$ ). Additionally, (2) the two most potent AChE inhibitors $8 \mathbf{q}$ and $8 \mathbf{r}$ possessed acceptable inhibitory activities against self-induced $A \beta(1-42)$ aggregation, with $\mathrm{IC}_{50}$ values of $17.36 \mu \mathrm{M}$ and $49.14 \mu \mathrm{M}$, respectively. The SAR analysis indicated that the introduction of a proper and relatively rigid group between the ester group and the benzene ring was beneficial to AChE inhibitory activity, and the replacement of the benzene ring moiety with a pyrazine unit or pyridine core also led to a dramatic increase in AChE inhibitory activity. A combined Lineweaver-Burk plot and molecular docking study revealed that these compounds might act as mixed-type inhibitors to exhibit such effects via selectively targeting both the CAS and the PAS of AChE. Moreover, the investigations of both the HepG2 cells and the SH-SY5Y cells showed that the potent "hits" 8q and 8r have a potent safe window for the next stage of the development of anti-AD drug discovery. Taken together, these results suggested that $\mathbf{8 q}$ and $\mathbf{8 r}$ could serve as promising candidates for the treatment of AD disorders and also provide a rational basis for the development of future multi-targeted inhibitors as anti-AD drugs with validated advantages over the classical anti-AD drug tacrine.

Supplementary Materials: The following are available online.

Author Contributions: W.W., G.X., L.C., W.L., and G.L. carried out the chemical synthesis; X.L., P.Z., and L.Y. performed the biological assay; X.Z. and H.J. performed the investigation of molecular docking. W.W., C.Z., and W.Y. analyzed the results and wrote the manuscript. All of the authors read and approved the final version of the manuscript.

Funding: This research was funded by the Foundation of Educational Commission of Guangdong Province of China (grant number: 2013KJCX0151, 2014KTSCX096 and 2016KQNCX129); Guangzhou science and technology project (grant number: 201707010008).

Conflicts of Interest: The authors declare no conflict of interest.

\section{References}

1. Mazon, J.N.; Mello, A.H.; Ferreira, G.K.; Rezin, G.T. The impact of obesity on neurodegenerative diseases. Life Sci. 2017, 182, 22-28. [CrossRef] [PubMed]

2. Fox, M. 'Evolutionary medicine' perspectives on Alzheimer's Disease: Review and new directions. Ageing Res. Rev. 2018, 47, 140-148. [CrossRef] [PubMed]

3. Alzheimer's, A. 2018 Alzheimer's disease facts and figures. Alzheimer's Dement. 2018, 14, 367-429.

4. Robertson, D.S. Proposed biochemistry of Parkinson's and Alzheimer's diseases. Med. Hypotheses 2017, 109, 131-138. [CrossRef] [PubMed]

5. Soler-Lopez, M.; Badiola, N.; Zanzoni, A.; Aloy, P. Towards Alzheimer's root cause: ECSIT as an integrating hub between oxidative stress, inflammation and mitochondrial dysfunction. Hypothetical role of the adapter protein ECSIT in familial and sporadic Alzheimer's disease pathogenesis. Bioessays 2012, 34, 532-541. [CrossRef] [PubMed]

6. Querfurth, H.W.; LaFerla, F.M. Alzheimer's disease. N. Engl. J. Med. 2010, 362, 329-344. [CrossRef] [PubMed]

7. Mohamed, T.; Osmana, W.; Tina, G.; Raoa, P.P. Selective inhibition of human acetylcholinesterase by xanthine derivatives: In vitro inhibition and molecular modeling investigations. Bioorg. Med. Chem. Lett. 2013, 23, 4336-4341. [CrossRef] [PubMed]

8. Karlsson, D.; Fallarero, A.; Brunhofer, G.; Mayer, C.; Prakash, O.; Mohan, C.G.; Vuorela, P.; Erker, T. The exploration of thienothiazines as selective butyrylcholinesterase inhibitors. Eur. J. Pharm. Sci. 2012, 47, 190-205. [CrossRef] [PubMed] 
9. Darvesh, S.; Cash, M.K.; Reid, G.A.; Martin, E.; Mitnitski, A.; Geula, C. Butyrylcholinesterase is associated with $\beta$-amyloid plaques in the transgenic APP SWE/PSEN1dE9 mouse model of alzheimer disease. J. Neuropathol. Exp. Neurol. 2012, 71, 2-14. [CrossRef] [PubMed]

10. Han, X.; He, G. Toward a Rational Design to Regulate $\beta$-Amyloid Fibrillation for Alzheimer's Disease Treatment. ACS Chem. Neurosci. 2018, 9, 198-210. [CrossRef] [PubMed]

11. Nalivaeva, N.N.; Turner, A.J. AChE and the amyloid precursor protein (APP)-Cross-talk in Alzheimer's disease. Chem. Biol. Interact. 2018, 259B, 301-306. [CrossRef] [PubMed]

12. Kumar, D.; Gupta, S.K.; Ganeshpurkar, A.; Gutti, G.; Krishnamurthy, S.; Modi, G.; Singh, S.K. Development of Piperazinediones as dual inhibitor for treatment of Alzheimer's disease. Eur. J. Med. Chem. 2018, 150, 87-101. [CrossRef] [PubMed]

13. Bolognesi, M.L. Polypharmacology in a single drug: Multitarget drugs. Curr. Med. Chem. 2013, 20, $1639-1645$. [CrossRef] [PubMed]

14. Khanam, H.; Ali, A.; Asif, M. Neurodegenerative diseases linked to misfolded proteins and their therapeutic approaches: A review. Eur. J. Med. Chem. 2016, 124, 1121-1141. [CrossRef] [PubMed]

15. Sahoo, A.K.; Dandapat, J.; Dash, U.C.; Kanhar, S. Features and outcomes of drugs for combination therapy as multi-targets strategy to combat Alzheimer's disease. J. Ethnopharmacol. 2018, 215, 42-73. [CrossRef] [PubMed]

16. Geldenhuys, W.J.; Van der Schyf, C.J. Rationally designed multi-targeted agents against neurodegenerative diseases. Curr. Med. Chem. 2013, 20, 1662-1672. [CrossRef] [PubMed]

17. Leon, R.; Garcia, A.G.; Marco-Contelles, J. Recent advances in the multitarget-directed ligands approach for the treatment of Alzheimer's disease. Med. Res. Rev. 2013, 33, 139-189. [CrossRef] [PubMed]

18. Ramsay, R.R.; Popovic-Nikolic, M.R.; Nikolic, K.; Uliassi, E.; Bolognesi, M.L. A perspective on multi-target drug discovery and design for complex diseases. Clin. Transl. Med. 2018, 7, 3-17. [CrossRef] [PubMed]

19. Dias, K.S.; Viegas, J.C. Multi-Target Directed Drugs: A Modern Approach for Design of New Drugs for the treatment of Alzheimer's Disease. Curr. Neuropharmacol. 2014, 12, 239-255. [CrossRef] [PubMed]

20. Peters, J.U. Polypharmacology-foe or friend? J. Med. Chem. 2013, 56, 8955-8971. [CrossRef] [PubMed]

21. Zheng, X.; Wu, F.; Lin, X.; Shen, L.; Feng, Y. Developments in drug delivery of bioactive alkaloids derived from traditional Chinese medicine. Drug Deliv. 2018, 25, 398-416. [CrossRef] [PubMed]

22. Xu, K.; Wang, P.; Xu, X.; Chu, F.; Lin, J.; Zhang, Y.; Lei, H. An overview on structural modifications of ligustrazine and biological evaluation of its synthetic derivatives. Res. Chem. Intermed. 2015, 41, 1385-1411. [CrossRef]

23. Zhu, X.L.; Xiong, L.Z.; Wang, Q.; Liu, Z.G.; Ma, X.; Zhu, Z.H.; Hu, S.; Gong, G.; Chen, S.Y. Therapeutic time window and mechanism of tetramethylpyrazine on transient focal cerebral ischemia/reperfusion injury in rats. Neurosci. Lett. 2009, 449, 24-27. [CrossRef] [PubMed]

24. Zhang, C.; Yan, W.; Zhao, R.; Xu, B.; Fang, X.; Yan, M.; Zhang, Y.; Wang, P.; Lei, H. Design, synthesis and evaluation of new ligustrazine derivatives as potential plasma-stable neuroprotective agents. MedChemComm 2017, 8, 652-656. [CrossRef] [PubMed]

25. Wang, M.; Qin, H.L.; Leng, J.; Ameeduzzafar, Z.; Amjad, M.W.; Raja, M.A.G.; Hussain, M.A.; Bukhari, S.N.A. Synthesis and biological evaluation of new tetramethylpyrazine-based chalcone derivatives as potential anti-Alzheimer agents. Chem. Biol. Drug. Des. 2018. [CrossRef] [PubMed]

26. Li, G.; Hong, G.; Li, X.; Zhang, Y.; Xu, Z.; Mao, L.; Feng, X.; Liu, T. Synthesis and activity towards Alzheimer's disease in vitro: Tacrine, phenolic acid and ligustrazine hybrids. Eur. J. Med. Chem. 2018, 14, $238-254$. [CrossRef] [PubMed]

27. Zhang, C.; Du, Q.Y.; Chen, L.D.; Wu, W.H.; Liao, S.Y.; Yu, L.H.; Liang, X.T. Design, synthesis and evaluation of novel tacrine-multialkoxybenzene hybrids as multi-targeted compounds against Alzheimer's disease. Eur. J. Med. Chem. 2016, 116, 200-209. [CrossRef] [PubMed]

28. Zhang, C.; Chen, L.D.; Liang, X.T.; Liu, W.X.; Wu, W.H. Synthesis and Biological Evaluation of Ligustrazine Derivatives. Chem. Nat. Comp. 2017, 53, 114-117. [CrossRef]

29. Ellman, G.L.; Courtney, K.D.; Andres Jr., V.; Feather-Stone, R.M. A new and rapid colorimetric determination of acetylcholinesterase activity. Biochem. Pharmacol. 1961, 7, 88-95. [CrossRef]

30. Huang, L.; Miao, H.; Sun, Y.; Meng, F.; Li, X. Discovery of indanone derivatives as multi-target-directed ligands against Alzheimer's disease. Eur. J. Med. Chem. 2014, 87, 429-439. [CrossRef] [PubMed] 
31. Sharma, A.K.; Pavlova, S.T.; Kim, J.; Finkelstein, D.; Hawco, N.J.; Rath, N.P.; Kim, J.; Mirica, L.M. Bifunctional compounds for controlling metal-mediated aggregation of the a $\beta 42$ peptide. J. Am. Chem. Soc. 2012, 134, 6625-6636. [CrossRef] [PubMed]

32. Nepovimova, E.; Uliassi, E.; Korabecny, J.; Peña-Altamira, L.E.; Samez, S.; Pesaresi, A.; Garcia, G.E.; Bartolini, M.; Andrisano, V.; Bergamini, C.; et al. Multitarget drug design strategy: Quinone-tacrine hybrids designed to block amyloid- $\beta$ aggregation and to exert anticholinesterase and antioxidant effects. J. Med. Chem. 2014, 57, 8576-8589. [CrossRef] [PubMed]

33. Colletier, J.P.; Sanson, B.; Nachon, F.; Gabellieri, E.; Fattorusso, C.; Campiani, G.; Weik, M. Conformational flexibility in the peripheral site of Torpedo californica acetylcholinesterase revealed by the complex structure with a bifunctional inhibitor. J. Am. Chem. Soc. 2006, 128, 4526-4527. [CrossRef] [PubMed]

34. Harel, M.; Schalk, I.; Ehretsabatier, L.; Bouet, F.; Goeldner, M.; Hirth, C.; Axelsen, P.H.; Silman, I.; Sussman, J.L. Quaternary Ligand Binding to Aromatic Residues in the Active-Site Gorge of Acetylcholinesterase. Proc. Natl. Acad. Sci. USA 1993, 90, 9031-9035. [CrossRef] [PubMed]

35. Rydberg, E.H.; Brumshtein, B.; Greenblatt, H.M.; Wong, D.M.; Shaya, D.; Williams, L.D.; Carlier, P.R.; Pang, Y.P.; Silman, I.; Sussman, J.L. Complexes of alkylene-linked tacrine dimers with Torpedo californica acetylcholinesterase: Binding of Bis5-tacrine produces a dramatic rearrangement in the active-site gorge. J. Med. Chem. 2006, 49, 5491-5500. [CrossRef] [PubMed]

36. Raves, M.L.; Harel, M.; Pang, Y.P.; Silman, I.; Kozikowski, A.P.; Sussman, J.L. Structure of acetylcholinesterase complexed with the nootropic alkaloid, (-)-huperzine A. Nat. Struct. Biol. 1997, 4, 57-63. [CrossRef] [PubMed]

37. Esquivias-Pérez, M.; Maalej, E.; Romero, A.; Chabchoub, F.; Samadi, A.; Marco-Contelles, J.; Oset-Gasque, M.J. Nontoxic and neuroprotective $\beta$-naphthotacrines for Alzheimer's disease. Chem. Res. Toxicol. 2013, 26, 986-992. [CrossRef] [PubMed]

38. Shi, C.; Zhao, L.; Zhu, B.; Li, Q.; Yew, D.T.; Yao, Z.; Xu, J. Protective effects of Ginkgo biloba extract (EGb761) and its constituents quercetin and ginkgolide B against $\beta$-amyloid peptide-induced toxicity in SH-SY5Y cells. Chem. Biol. Interact. 2009, 181, 115-123. [CrossRef] [PubMed]

39. González-Muñoz, G.C.; Arce, M.P.; López, B.; Pérez, C.; Romero, A.; del Barrio, L.; Martìn-de-Saavedra, M.D.; Egea, J.; León, R.; Villarroya, M.; et al. N-acylaminophenothiazines: Neuroprotective agents displaying multifunctional activities for a potential treatment of Alzheimer's disease. Eur. J. Med. Chem. 2011, 46, 2224-2235. [CrossRef] [PubMed]

Sample Availability: Not available

(C) 2018 by the authors. Licensee MDPI, Basel, Switzerland. This article is an open access article distributed under the terms and conditions of the Creative Commons Attribution (CC BY) license (http:/ / creativecommons.org/licenses/by/4.0/). 